No 2013-06

February

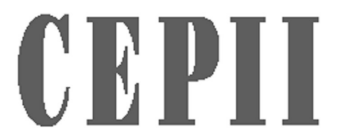

CENTRE

D'ÉTUDES PROSPECTIVES

ET D'INFORMATIONS

INTERNATIONALES

Product Standards and Margins of Trade:

Firm Level Evidence

Lionel Fontagné, Gianluca Orefice, Roberta Piermartini, Nadia Rocha 


\section{TABLE OF CONTENTS}

Non-technical summary. . . . . . . . . . . . . . . . . . . . . . . . . . . 3

Abstract . . . . . . . . . . . . . . . . . . . . . . . . . . . . . . 4

Résumé non technique . . . . . . . . . . . . . . . . . . . . . . . . . . 5

Résumé court . . . . . . . . . . . . . . . . . . . . . . . . . . 6

Introduction . . . . . . . . . . . . . . . . . . . . . . . . . . . . . 7

1. Data and Stylized facts. . . . . . . . . . . . . . . . . . . . . . . . . . 9

1.1. Specific Trade Concerns database. . . . . . . . . . . . . . . . . . . . 9

1.2. French firms export data . . . . . . . . . . . . . . . . . . . . . . . 19

2. Empirical Strategy . . . . . . . . . . . . . . . . . . . . . . . . . . . 20

3. Results . . . . . . . . . . . . . . . . . . . . . . . . . . . 22

3.1. SPS and the extensive margin of trade . . . . . . . . . . . . . . . . . . 22

3.2. SPS and the intensive margin of trade . . . . . . . . . . . . . . . . . . 24

3.3. SPS and firms' pricing . . . . . . . . . . . . . . . . . . . . . . . . 25

3.4. Endogeneity . . . . . . . . . . . . . . . . . . . . . . . . . . 27

4. Conclusion . . . . . . . . . . . . . . . . . . . . . . . . . . 32

References . . . . . . . . . . . . . . . . . . . . 33

Appendix . . . . . . . . . . . . . . . . . . . . . . . . . . . . . . 34

List of working papers released by CEPII . . . . . . . . . . . . . . . . . . . . 36 


\title{
Product Standardis and Margins of Trade: FIRM LEVEL EVIDENCE
}

\author{
Lionel Fontagné, Gianluca Orefice, Roberta Piermartini, Nadia Rocha
}

\section{NON-TECHNICAL SUMMARY}

World average applied protection in 2007 was 4.4 per cent and only 3.2 per cent for manufactured products. It suggests a quite easy access to foreign markets. Such image, however, hardly matches the levels of overall protection revealed by indirect evidence on measures e.g. provided by border effects (De Sousa et al., 2011). Together these two views point at the presence of important non-tariff measures (NTMs) hampering trade.

Hence, this paper addresses the trade effect of restrictive product standards on the margins of trade, by matching a detailed panel of French firm exports with a new database compiling the list of measures that have been raised as a concern in the dedicated committees of the WTO. In particular, we restrict our analysis to the subset of Sanitary and Phyto-Sanitary (SPS) regulatory measures. We estimate the effect of SPS imposition (in a certain market and product) on the intensive and extensive margins of trade. We also study the effect of SPS on firms exit probability and trade unit values. The value added of this paper with respect the existing literature is twofold. First, we use only trade affecting measures, indeed a concern is raised to the WTO if the measure really affects trade. Second, we use firm level data to proper study the NTMs effect on both extensive and intensive margins of trade by also considering the heterogeneity of firms (large vs. small firms).

We find that SPS concerns have a negative impact on both the extensive and intensive margins of trade, meaning that SPS represents a further fixed or variable cost to entry the foreign markets. According to our results, facing a SPS concern reduces the probability to export by 2.2 per cent; we also find a differentiated effect of SPS concerns across heterogeneous firms: the negative impact of SPS is reduced for big players exporting a lot in several countries and sectors. Beyond high productivity and better ability to cope with additional cost, our interpretation of this result is that big players, having wide sector-market portfolios, can smooth the additional cost implied by SPS by moving resources from unaffected to SPS imposing sector-market; also they take benefit of reduced competition to increase their market share in a smaller import market.

We also find that in presence of SPS concerns, exporting firms increase the price of their exported goods, meaning that SPS, by reducing the competition in the destination market, allows firms to charge a higher price. This effect is stronger the higher the importance of the destination market for French exports. 
Overall, our results show that SPS imposition is not just a trade deterring measure. It rather implies a complex set of effects including market participation and quality upgrading. Moreover, the effect of SPS measures strictly depends on firms' characteristics.

\begin{abstract}
This paper analyses the trade effects of restrictive product standards on the margins of trade for a large panel of French firms. To focus on restrictive product standards only, we use a new database compiling the list of measures that have been raised as concerns in dedicated committees of the WTO. We restrict our analysis to the subset of Sanitary and Phyto-Sanitary (SPS) regulatory measures and analyse the effects of product standards on three variables: (i) probability to export and to exit the export market (firm-product extensive margins), (ii) value exported (firm-product intensive margin) and (iii) export prices. In particular we study whether firms size, market shares and export orientation modify the effect of SPS measures. We find that SPS measures discourage exports. We also find a negative effect of SPS imposition on the intensive margins of trade. Finally, the negative effects of SPS measures on the extensive and intensive margins of trade are attenuated for big firms.
\end{abstract}

\title{
JEL Classification: F12, F15.
}

Keywords: $\quad$ International trade, firm heterogeneity, multi-product exporters, non-tariff barriers 


\section{ar \\ CEPII

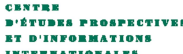

NORMES ET MARGES DU COMMERCE: UN EXAMEN AU NIVEAU DES FIRMES

Lionel Fontagné, Gianluca Orefice, Roberta Piermartini, Nadia Rocha

\section{RÉSUME NON TECHNIQUE}

La moyenne mondiale des droits de douane était en 2007 de 4,4\% et de seulement 3,2\% pour les produits manufacturés. Ces chiffres laissent penser que l'accès aux marchés étrangers est facile, contrairement à ce qu'indiquent des mesures indirectes des niveaux de protection telles que les effets frontières (De Sousa et al., 2011). L'importance de la protection non tarifaire permet de réconcilier ces deux observations.

L'objet de notre travail est d'étudier les effets des mesures non tarifaires sur les exportations. A cet effet, nous apparions une base de données des exportations françaises détaillée au niveau des entreprises avec une nouvelle base de données contenant la liste des mesures examinées dans les comités spécialisés de l'Organisation Mondiale du Commerce (OMC). Nous limitons notre analyse aux mesures sanitaires et phytosanitaires (SPS).

Nous estimons l'effet de la mise en place d'une mesure SPS (pour un certain produit sur un certain marché) sur les marges extensive et intensive du commerce international (présence sur les marchés et valeurs exportées sur chacun), sur les prix des biens échangés et, enfin, sur la probabilité de sortie des entreprises du marché d'exportation considéré. Notre apport à la littérature existante est double : (1) concentrant notre analyse sur les mesures examinées par les comités de l'OMC, nous traitons uniquement de celles qui affectent réellement les exportations; (2) utilisant des données de firmes, nous étudions les effets des mesures SPS en tenant compte de l'hétérogénéité des firmes.

Nos résultats confirment que les mesures sanitaires et phytosanitaires ont un impact négatif sur les marges extensive et intensive du commerce : une mesure SPS représente un coût supplémentaire (fixe ou variable) à l'entrée sur les marchés étrangers. Selon nos résultats, l'introduction d'une mesure SPS réduit la probabilité d'exportation de 2,2\%. Cependant cet impact diffère selon la taille des entreprises : il est moins élevé pour les gros exportateurs. Au-delà d'une productivité élevée et d'une meilleure capacité à faire face à des frais supplémentaires, notre interprétation de ce résultat est que les grandes entreprises disposent de portefeuilles de produits suffisamment étendus pour allouer des ressources des secteurs non affectés par les SPS vers ceux qui le sont; ces grandes entreprises peuvent également profiter d'une diminution de la concurrence sur les marchés touchés par les SPS pour y augmenter leurs parts.

Nos résultats montrent aussi que les firmes augmentent les prix des biens qu'elles exportent lorsque ceuxci sont affectés par des mesures SPS ; on peut penser que c'est la moindre concurrence sur ces marchés qui leur permet d'augmenter leurs prix. Cet effet est d'autant plus fort que le marché de destination est important pour les firmes françaises. 
Au total, nos résultats montrent que les mesures SPS n'ont pas seulement pour effet de réduire les exportations agrégées; elles impliquent un ensemble d'effets microéconomiques qui modifient notamment la participation au marché et les prix à l'exportation. Dès lors l'effet attendu des mesures SPS dépend des caractéristiques des entreprises et du degré de concurrence des marchés.

\section{RÉSUMÉ COURT}

Cet article examine comment des normes restrictives sur les produits affectent les différentes marges du commerce international. Afin de ne considérer que les normes ayant un véritable effet restrictif, nous utilisons une nouvelle base de données compilant l'ensemble des mesures ayant fait l'objet d'un examen par les comités spécialisés de l'OMC. Nous restreignons notre analyse au sous-ensemble des mesures réglementaires Sanitaires et Phyto-Sanitaires (SPS). Nous analysons l'impact des SPS examinées sur trois variables: (i) la probabilité d'exporter vers un marché ou d'en sortir (marge extensive firme-produit); (ii) la valeur des exportations (marge intensive firme-produit) et (iii) le prix des exportations. Nous examinons en particulier si la taille des firmes, leur part de marché ou l'orientation de leurs exportations modifient l'impact des SPS. Nous observons que les SPS réduisent la présence de certains exportateurs, ainsi que la valeur des exportations pour les autres. La participation est toutefois moins affectée dans le cas des grandes firmes.

\section{Classification JEL : F12, F15}

Mots clés : $\quad$ Commerce international, hétérogénéité des firmes, exportateurs multi-produits, barrières non-tarifaires 


\title{
Product Standards and Margins of Trade: FIRM LEVEL EVIDENCE
}

\author{
Lionel Fontagné * \\ Gianluca Orefice ${ }^{\dagger}$ \\ Roberta Piermartini ${ }^{\ddagger}$ \\ Nadia Rocha ${ }^{\S}$
}

\section{INTRODUCTION}

The significant reduction in the level of tariffs over the several rounds of World Trade Organization (WTO) negotiations, proliferation of regional trade agreements and unilateral liberalization has increasingly highlighted the importance of non-tariff measures as barriers to trade. ${ }^{1}$ In fact, while the world average applied tariffs is as low as 3.2 per cent for manufactured products, estimates of the overall level of barriers to trade provide much higher figures (De Sousa et al., 2011). ${ }^{2}$

Several studies attempt to quantify the effect of non-tariff measures on international trade. But, their results are based on data that are outdated, refer to a selected sample or mix very different types of measures. For example, Kee et al. (2009), using data on Non-Tariff Measures (NTMs) from TRAINS, estimate an average ad valorem equivalent for the core $\mathrm{NTMs}^{3}$ of 12 per cent. However, data on NTMs refer to 2001 and they have not been updated since. The number of products, importing countries and regulations make the data collection exercise very costly. Furthermore, the TRAINS database only records whether a country imposes an NTM without indicating whether the measure is a barrier to trade or not. This can be a relevant problem

\footnotetext{
*Paris School of Economics (Université Paris I), European University Institute and CEPII. Email: lionel.fontagne@univ-paris1.fr

${ }^{\dagger}$ CEPII, Paris. Email: gianluca.orefice@ cepii.fr

${ }^{\ddagger}$ ERSD, WTO Geneva. Email: roberta.piermartini@wto.org

${ }^{\S}$ ERSD, WTO Geneva. Email: nadia.rocha@wto.org

${ }^{1}$ We are grateful to participants of GTAP conference 2012 (Geneva), ETSG 2012 (Leuven) and GTDW workshop in Geneva. We thank also Matthieu Crozet, Javier Ocampo, Lee Ann Jackson and Gretchen Stanton. The views presented in this article are those of the authors and do not reflect the World Trade Organization. They are not meant to represent the positions or opinions of the WTO and its Members and are without prejudice to Members' rights and obligations under the WTO. Gianluca Orefice was affiliated to the WTO in the early phases of this research project. Customs data were acceded at CEPII.

${ }^{2}$ They estimate overall barriers as high as 82 per cent for north-north trade and of 118 per cent for north-south imports.

${ }^{3}$ Core NTMs are defined as including price control measures, quantitative restrictions, monopolistic measures, antidumping and countervailing measures and technical regulations.
} 
especially in the case of regulatory measures. For instance, a regulation that addresses the problem of incomplete information on the attributes of credence goods may actually foster trade rather than hindering it. Other studies rely on survey data. Indeed, International Trade Center (ITC, Geneva) is engaged in an effort to conduct surveys on exporters' perception of obstacles to access foreign markets. However, albeit informative, these data are not a systematic record of all barriers. Similar concerns arise with the studies that use the WTO notification database as a source for non-tariff barriers. This is because not all countries have the same propensity to notify their measures to the WTO. Therefore, the picture of NTMs in force that the notification database provides may be biased.

This paper also analyses the effect of non-tariff measures on trade. Our contribution to the existing literature is twofold. First, we overcome the data limitation of previous literature by using a new database: the WTO database on specific trade concerns. This database records the concerns that have been raised in dedicated committees of the WTO. In particular, we focus on the concerns raised in the Committee on Sanitary and Phytosanitary measures (SPS). The advantage of using this information is that it provides a systematic collection of all measures that are perceived as sizeable barriers to trade by exporters. In this context, "sizeable" means that they are perceived so important that countries whose exports are affected by the measure raise a "concern" at the SPS committee of the WTO. We are aware that, for the purpose of our estimations, a potential drawback of such approach is that it may enhance endogeneity problems. Therefore, in the paper we cautiously address endogeneity, including through instrumental variables estimations.

The second contribution of our paper is to explore the effects of NTM on several dimensions of heterogeneous firms behavior. In particular, we look at changes in firms' behaviour when confronted to regulatory barriers in terms of participation in the export market, values of exports and pricing strategy. As highlighted by Baldwin (2001), NTMs can be thought as both fixed and variable costs for exporting firms. Assuming the existence of a fixed cost to entry in a certain market, recent trade models (Melitz, 2003) predict that only the most productive firms in the industry will continue to export after an increase in such fixed cost. Therefore, the imposition of a new import standard could affect both the probability to enter in a foreign market (extensive margin) and its associated exported value (intensive margin). The quantification of these effects is clearly an empirical matter. However, most of the existing literature on non-tariff measures is based on aggregate trade flows. Therefore, it cannot shed any light on how firms' specific patterns of trade are affected by NTMs. ${ }^{4}$

To the best of our knowledge only two other works analyse the effect of NTMs at firm level. Chen, Otsuki and Wilson (2006) use the World Bank Technical Barrier to Trade Survey (2004) - including 619 firms in 24 agricultural and manufacturing industries and 17 developing countries - and find that testing procedures imposed by potential destination markets reduce export

\footnotetext{
${ }^{4}$ See, for example, Moenius (2004) and Disdier et al. (2008).
} 
shares by 19 per cent. ${ }^{5}$ Reyes (2011) examines the response of US manufacturing firms in the electronic sector to a reduction of NTMs by looking at the harmonization of European product standards to international norms. Using US Longitudinal Firm Trade Transaction Database (LFTTD) data, Reyes finds that product standards harmonization increases the probability that high-productivity firms enter the EU market whereas tariffs do not affect entry decision.

Our paper is the first to study the impact of non-tariff barriers on firms' exports using a long time period (10 years), covering all HS-4 sectors and analysing firms' actual behaviour rather than their replies to surveys. To this purpose, we use individual firms export data provided by the French customs for 1995-2005. ${ }^{6}$

We find that SPS concerns have a negative impact on both the extensive and intensive margins of trade. According to our preferred estimation, we estimate that SPS measures that have triggered the exporting country to raise a concern at the WTO SPS-committee reduce the probability to export by 2.2 per cent. Moreover, in presence of SPS concerns, exporting firms significantly increase the price of their exported goods.

We also find a differentiated effect of SPS concerns across heterogeneous firms: the negative impact of SPS is reduced for big players, that is firms exporting a lot in several countries and sectors. Beyond high productivity and better ability to cope with additional costs, our interpretation of this result is that big players, having wide sector-market portfolios, can smooth the additional cost implied by SPS by moving resources from unaffected to SPS imposing sectormarket; also they benefit from reduced competition to increase their market share in smaller import market.

The paper is organised as follows. Section 2 describes the data and some stylised facts. Section 3 discusses our empirical strategy. Section 4 presents the results. The final section concludes.

\section{DATA AND Stylized FaCtS}

This paper relies on two major databases: a recently built database on specific trade concerns (STCs) and a database of French firms' exports.

\subsection{Specific Trade Concerns database}

The WTO has recently released a new database on SPS measures ${ }^{7}$. This database is based on the work undertaken in the context of SPS Committee of the WTO. This committee provides WTO members with a forum to discuss issues related to SPS measures taken by other members.

\footnotetext{
${ }^{5}$ In Chen et al.(2006) export share is the ratio between firm's exports and its total sales.

${ }^{6}$ We have information about shipments bigger than 2500 euros.

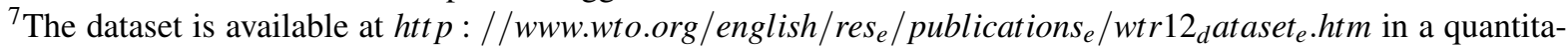
tive format and in a searchable format in http://spsims.wto.org/web/pages/search/stc/Search.aspx.
} 
These issues are referred to as "specific trade concerns" (STCs). When a country raises a concern at the SPS Committee over a measure (whether draft or in force), it specifies the product of concern, the type of concern about the measure and the objective of the measure concerned.

Overall, the SPS STCs database contains information on 312 specific-trade concerns raised over the period 1995-2011. Each STC corresponds to a concern raised by one or several countries in relation to a SPS measure maintained by one or more of their trading partners. For each concern, we have information on: (i) the country or countries raising the concern and the country imposing the measure, (ii) the product codes (HS 4-digit) involved in the concern, (iii) the year in which the concern has been raised to the WTO and (iv) whether it has been resolved and how. Our analysis focuses on a sub-sample of 80 concerns raised by the EU over the period 1996-2005 -the period for which we have information on French firm-level exports.

Approximately 45 per cent of all concerns raised between 1996 and 2005 were reported as resolved or partially solved by WTO members to the SPS Committee. Most of these solved concerns ended up in a gentleman agreement whereby the importing and exporting countries managed to fix the problem without resorting to a WTO panel. Among the concerns raised by the EU, a slightly higher share has been reported as solved or partially solved (50 per cent). Only 5 percent of all concerns ended up in a dispute at WTO (6 per cent for concerns raised by the EU). In addition, the average time length between when a concern is first raised and when is reported to be solved is about 3 years.

SPS measures that have been subject to a concern are very diversified. STCs are raised in relation to measures protecting human, animal or plant life or health. In some cases, countries require a clarification about the scope and the status of the measure. In other cases, the concerns relate to the perceived discriminatory or trade-restrictive nature of the measure. Finally, SPS measures cover food and agriculture as well as manufacturing products. Between 1996 and 2005,40 per cent of concerns raised related principally to animal health and zoonoses, 28 per cent related to food safety, 26 per cent to plant health, and 6 per cent to other issues such as certification requirements and transparency. ${ }^{8}$ Similarly, 39, 30, 25, 6 per cent of STCs raised by the EU relate to animal health, food safety, plant health and other issues, respectively. It is worth noting, however, that animal health-related concerns mainly relate to foot-and-mouth disease, transmissible spongiform encephalopathies and avian influenza. All these issues obviously also concern food safety. Therefore, a one-to-one count of STCs and related object of the concern is only approximated.

STCs are very different also in terms of the nature of the concern. Several STCs are related to the restrictiveness of the specification of the standard, others to the inspection procedure and other still to the transparency of the measure. Table 1 provides an overview of the typology of STCs raised in the WTO SPS Committee between 1996 and 2005.

One example of a concern over the transparency of a measure is the concern raised in June

\footnotetext{
${ }^{8}$ WTO Committee on SPS, 2005, G/SPS/53.
} 
Table 1 - A typology of SPS-related STCs. 1996-2005

\begin{tabular}{lcc}
\hline \hline & All Concerns & Concerns raised by the EU \\
\hline Standards & 84 & 31 \\
Conformity Assessment & 81 & 24 \\
Emergency & 43 & 16 \\
Transparency & 16 & 5 \\
Other & 67 & 20 \\
\hline Source: Authors calculations on STCs database, WTO
\end{tabular}

2004 by the European Union together with United States, Australia, and New Zealand against several SPS measures adopted by the Indian Government. The raising countries indicated that India's non-notification, or late notification, of various SPS measures had created unnecessary trade disruptions and an uncertain environment for trade. In 2005, the European Union and the United States again expressed concern regarding India's non-compliance with its transparency obligations under the SPS Agreement and requested India to suspend the implementation of measures on dairy products and pet food until a WTO notification was made available and a reasonable time provided to Members for their review and comment. India explained that it had recently notified the establishment of three separate enquiry points with clearly delineated responsibilities. These efforts had achieved greater coordination among agencies, as demonstrated by the number of recent notifications that had been submitted at an early stage in the development of the regulation and with a due period for comments. ${ }^{9}$

Several concerns relate to conformity assessment procedures. For example, in March 1997 the European Union questioned Brazil's measure on wine exports. In particular, the EU expressed concern over certification requirements for individual consignments rather than more general, generic types of certification. ${ }^{10}$ Another example is the concern the EU raised in 2005 over the US procedures for the importation of fruits and vegetable. The EU claimed that, because of the length of the inspection procedures, its exporters of fruits and vegetables were experiencing significant losses. This latter concern related also to the restrictiveness of the measure itself. The EU expressed also concern that US Animal and Plant Health Inspection Service required that only US-produced pesticides be used during cultivation, some of which were not permitted within the European Union. On the other hand, certain insects used to protect crops in the European Union were not allowed entry into the United States. The EU requested the United States to accept the use of equivalent pesticides. The United States replied that pesticides did not have to be produced in the United States, but to be registered on the Environmental Protection Agency list of authorized pesticides. ${ }^{11}$

Furthermore, SPS concerns go beyond food and agricultural sectors to include manufacturing. One example is the concern raised by the EU against Chinese import requirements for cosmet-

\footnotetext{
${ }^{9}$ WTO documents G/SPS/R/34,G/SPS/R/35, G/SPS/R/36/Rev.1 G/SPS/R/37/Rev.1.

${ }^{10} \mathrm{WTO}$ documents G/SPS/R/5 and G/SPS/R/7.

${ }^{11}$ WTO document G/SPS/R/37/Rev.1.
} 
ics. ${ }^{12}$ The new regulations prohibited cosmetics containing certain ingredients of animal origin from 18 countries. The regulation was introduced in connection with risks associated to the existence of Bovine Spongiform Encephalopathy (BSE). Cosmetics from these 18 countries required certification that they did not contain specified products of bovine or ovine origin. In June 2003, the European Union reported that further progress was made as China had presented a list of prohibited products. China responded that it was willing to review its regulations and welcomed continued dialogue.

A detailed analysis of the typology of SPS-related STCs shows that SPS measures, although their behind-the-border nature, are far from being non-discriminatory. On the contrary, they can discriminate not only between domestically produced and imported products, but also across type of exporting firms or potentially against specific exporting firms. Very interesting for the purpose of the analysis of this paper is the concern raised by the EU in 1998 related the US requirement on refrigeration and labelling requirements for shell eggs. The EU required clarifications regarding the non-application of the measure to production units with 3000 hens or less, and asked the United States to explain the discrimination between foreign and domestic eggs. ${ }^{13}$ The measure is still maintained by the United States and a solution of the concern has not been reported to the WTO as of March 2011. ${ }^{14}$ This example shows that a measure can be, by its mere design, discriminatory against some firms- large exporting firms in the case above. In addition, given that imports of goods regulated by a certain SPS measure need to be inspected and certified, the potential exists that SPS measures are applied in a discriminatory manner. Requests of certification for individual consignments or lengthy inspection can potentially target specific firms. Hence, the need for our firm-level analysis for an appropriate evaluation of the impact of SPS measures on trade.

The advantage of using specific trade concerns as an index of restrictiveness of product standards compared to notification or traditional sources of information on the existence of a regulation is that they point out those measures that are perceived by the exporters and/or by the government as major obstacles to trade. This means that the information they provide relates to trade restrictive measures only. In contrast, the measures of non-tariff barriers traditionally used in the existing literature, based on TRAINS or Perinorm database or WTO notifications, do not distinguish between product standards that restrict trade or measures that may even increase trade, such as measures that address problems of asymmetric information or network externalities (Moenius, 2004; Fontagné et al., 2005). Therefore, existing studies fail to account for the actual trade restrictive effect of specific measures.

The use of specific trade concerns as a measure of restrictiveness also allows us to account for the exact timing of when the measure is perceived as a barrier. For example, in 1998, the EU requested Australia to identify the international standard on which its import ban on Roque-

\footnotetext{
${ }^{12}$ WTO documents G/SPS/R/27, G/SPS/R/28,G/SPS/R/3.

${ }^{13}$ WTO documents G/SPS/R/13.

${ }^{14}$ WTO document G/SPS/GEN/204/Rev.11/Add.2.
} 
fort cheese was based, or to provide scientific justification and a risk assessment. Australia's risk assessment on Roquefort cheese had identified potential problems with pathogenic microorganisms and French Roquefort did not comply with Australian requirements. The measure restricting imports of Roquefort into Australia, however, had been put in place before 1 January 1995, but compliance had recently been reinforced. ${ }^{15}$ It is only at the moment in which the implementation of the measure was made effective that the measure was perceived as a barrier not before.

In addition, STCs highlight the specific product of concern rather than the product on which the measure is applied. Information about product coverage in a notification and in a STC might diverge. For example, it may be the case that notifications cover a broad range of products, while the concern raised by a country pertains only to a subset of products covered by the measure.

A potential problem with the use of STCs is that they can either be related to a measure currently in force or to a new measure notified at the WTO. When STCs refer to a new measure, except for the case of an emergency measure, they can be raised as early as 8 months before the new regulation enters into force. ${ }^{16}$ Therefore, estimates of the impact of measures subject to STCs on trade can potentially be downward biased. To the extent that our estimations are significant, this issue does not undermine our findings. Furthermore, this issue is partially addressed by our using the lag of STCs because measures relative to STCs raised the year before are in fact likely to be in place.

Compatibly with the general perception that the relevance of non-tariff measures as barrier to trade has become increasingly more important, the cumulative number of unresolved SPSrelated STCs shows an upward trend both in terms of the number of countries maintaining SPS measures object of a STC and the number of products covered by a concern. Figure 1 shows that the number of countries maintaining SPS measures object of STCs doubled in the period 1996-2005. After 2005, this number continued to increase and reached a peak in 2009. This trend is compatible with the general perception of increased protectionism after the crisis, thus again showing that STCs may indeed capture barriers to trade. The count of the number of HS4 product lines for which a concern was raised also increased between 1995 and 2011 (Figure 2).

STCs tend to be concentrated against a handful of countries. In particular, the map in Figure 3 shows that relatively few concerns are raised against small economies. This does not neces-

\footnotetext{
${ }^{15}$ WTO documents G/SPS/R/11 and Corr.1, G/SPS/R/13, G/SPS/R/14.

${ }^{16}$ The WTO agreement requires members to notify new measures that may have a "significant effect on trade" at their drafting stage and to allow a reasonable period of time (normally 60-days) for submission, discussion and consideration of comments before the adoption of the measure (Paragraph 5(d) of Annex B of the SPS Agreement and WTO document G/SPS7/Rev.3). In addition, in accordance with paragraphs 1 and 2 of Annex B of the SPS Agreement, Members are obliged to: (a) "ensure that all SPS regulations which have been adopted are published promptly", and (b) " allow a reasonable interval between the publication of a sanitary or phytosanitary regulation and its entry into force". As agreed in the Doha Decision on Implementation-Related Issues and Concerns (WT/MIN(01)/17, para. 3.2): "the phrase "reasonable interval" shall be understood to mean normally a period of not less than 6 months".
} 
sarily indicate that small countries do not use SPS measures that may restrict trade. Instead, it might be the case that raising concerns is costly. Therefore, countries limit the concerns they raise in the WTO Comittee to those against large export markets. Another explanation may be that richer countries are more sensitive to food safety issues than poorer countries. Therefore, rich countries will impose more numerous and stringent measures than poor coutries and this, in turn, will reflect in a greater number of concerns against the former. Table 2 shows the distribution of concerns by country imposing the problematic measure. Column (1) shows for each imposing country the number of products (counted at the HS4) interested by a concern raised by a WTO member. The figures in this column show that, over the period 1996-2005, 40 per cent of all products interested by a concern were about measures introduced by the European Union, United States, India, China and Japan. However, when we take jointly into account that a concern may refer to several products (column 1), that the measure imposed by a country may be a concern for several raising countries (column 2) and weight the relevance of each concern by the number of years during which a concern remains unresolved (column 3), the range of countries that have a substantial involvement in STCs substantially increases. For example, concerns raised against Turkey, Switzerland, Argentina, Korea, and Indonesia show figures for the index built in column 3 that are two times above the average (equal to 335).

The concerns raised by the EU, Table 2 (column 4 and 5) show very similar patterns. EU concerns against measure introduced by United States, India, China and Japan cover 45 per cent of all products interested by a concern. When the duration of concerns is taken into account, Turkey, Canada, Argentina, and Korea also figure prominently (the index in column 3 is twice above its average).

Figure 1 - Countries object of SPS (number)

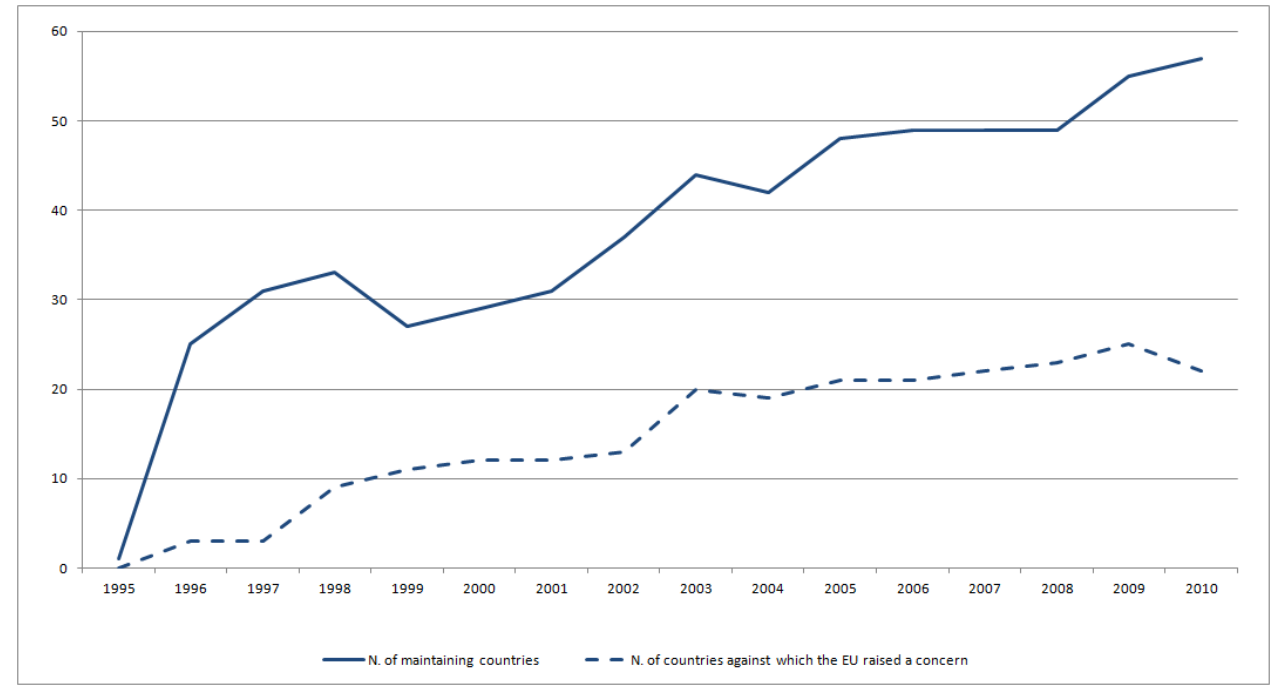

Source: Authors calculations on STC database, WTO 
SPS-related trade concerns have been raised with respect to a variety of sectors. Table 3 lists the sectors (at the HS2 level) for which at least one concern was raised in the period 19962005. ${ }^{17}$ For each sector, the table provides information on the number of countries that have raised a concern (column 1), the number of countries time the number of products at the HS4 level covered by the concern (column 2) and the latter times the number of years during which the concern remain unresolved (column 3).

The distribution of STCs appears concentrated in a handful of sectors. In terms of the number of countries against which a concern was raised by a WTO member, Meat and edible meat offal (Chapter 2), Dairy products, birds' eggs and natural honey (Chapter 4) and Edible fruits and nuts (chapter 8), and Edible vegetable (Chapter 7) are the sectors most affected by STCs (the number of countries raising a concern in relation to trade in these sector is twice the average).

However, when we look at the index of the number of countries-product-year of concerns, Animal and vegetable fats and oils (Chapter 15) and Wood and articles of wood (Chapter 44) also show up predominantly (index is twice as the average). In terms of the same index, Chapters 2, 4, and 44 are the top three sectors most affected by STCs raised by the EU. Overall, STCs raised by the EU are representative of the sectoral patterns of STCs raised by all WTO members. There are only six HS2 sectors (sugar, for example) for which the EU has no STCs in the period 1996-2005 while other WTO countries have.

Figure 2 - Products covered by SPS (number of HS4 lines)

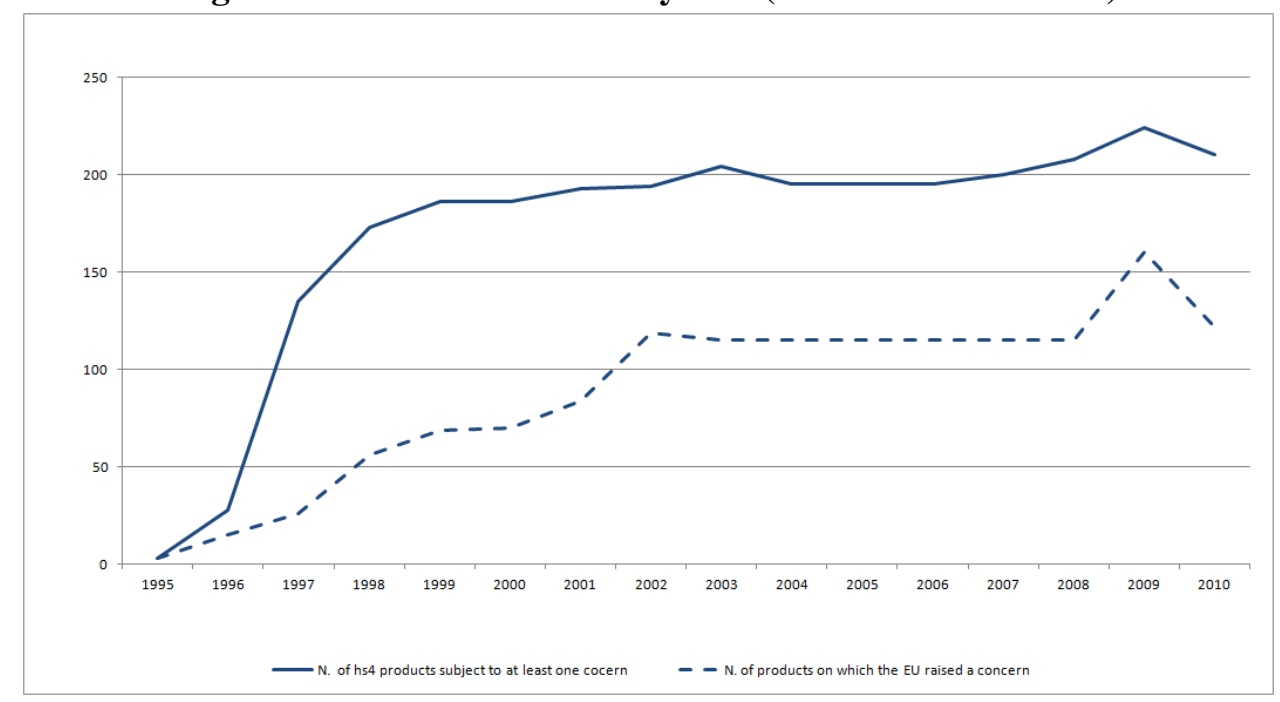

Source: Authors calculations on STC database, WTO

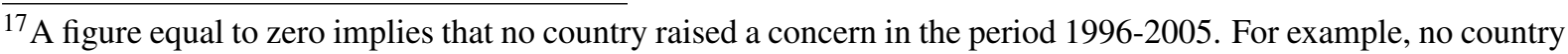
raised a concern on a product falling under Chapter 51 (wool). But, since chapter 51 listed in the table, some country must have raised a concern in relation to wool in the period 2006-2011.
} 


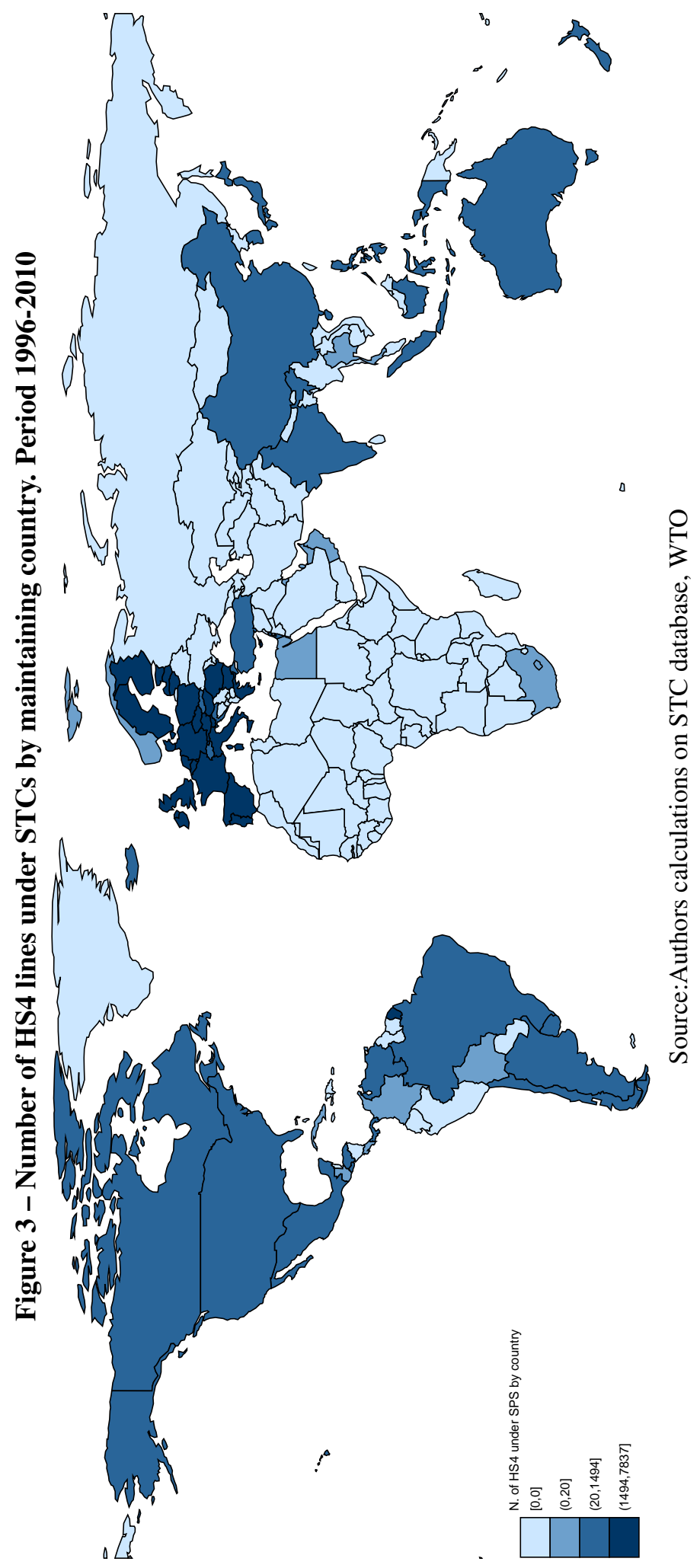


Table 2 - Distribution of STCs by maintaining country

\begin{tabular}{|c|c|c|c|c|c|}
\hline \multirow[b]{2}{*}{ Maintaining Country } & \multicolumn{3}{|c|}{ Concerns raised by at least one country in the world } & \multicolumn{2}{|r|}{ Concerns raised by the EU } \\
\hline & Products & $\begin{array}{c}\text { Products and } \\
\text { countries }\end{array}$ & $\begin{array}{c}\text { Products, countries } \\
\text { and years }\end{array}$ & Products & $\begin{array}{c}\text { Products and } \\
\text { years }\end{array}$ \\
\hline & $(1)$ & $(2)$ & $(3)$ & (4) & $(5)$ \\
\hline Bahrain & 1 & 1 & 3 & 1 & 3 \\
\hline Barbados & 1 & 1 & 2 & 0 & 0 \\
\hline Colombia & 1 & 1 & 1 & 0 & 0 \\
\hline Egypt & 1 & 1 & 6 & 0 & 0 \\
\hline Kuwait & 1 & 1 & 3 & 1 & 3 \\
\hline Oman & 1 & 1 & 3 & 1 & 3 \\
\hline Qatar & 1 & 1 & 3 & 1 & 3 \\
\hline United Arab Emirates & 1 & 1 & 3 & 1 & 3 \\
\hline Bolivia & 2 & 2 & 2 & 0 & 0 \\
\hline Guatemala & 2 & 3 & 3 & 1 & 1 \\
\hline Norway & 2 & 2 & 4 & 0 & 0 \\
\hline Thailand & 2 & 2 & 2 & 0 & 0 \\
\hline Honduras & 3 & 6 & 30 & 0 & 0 \\
\hline South Africa & 3 & 4 & 20 & 1 & 8 \\
\hline Trinidad and Tobago & 3 & 3 & 12 & 0 & 0 \\
\hline Austria & 4 & 4 & 12 & 0 & 0 \\
\hline Cuba & 4 & 4 & 11 & 0 & 0 \\
\hline Italy & 4 & 4 & 12 & 0 & 0 \\
\hline Netherlands & 4 & 4 & 12 & 0 & 0 \\
\hline Singapore & 4 & 4 & 12 & 0 & 0 \\
\hline Slovenia & 4 & 4 & 12 & 0 & 0 \\
\hline France & 5 & 6 & 30 & 0 & 0 \\
\hline Hungary & 6 & 6 & 18 & 0 & 0 \\
\hline Mexico & 6 & 12 & 38 & 2 & 6 \\
\hline Czech Republic & 7 & 9 & 37 & 2 & 9 \\
\hline New Zealand & 7 & 50 & 228 & 7 & 24 \\
\hline Slovak Republic & 7 & 13 & 61 & 2 & 9 \\
\hline Greece & 8 & 8 & 8 & 0 & 0 \\
\hline Belgium & 9 & 9 & 47 & 0 & 0 \\
\hline Iceland & 10 & 10 & 40 & 0 & 0 \\
\hline United Kingdom & 10 & 10 & 10 & 0 & 0 \\
\hline Uruguay & 10 & 20 & 80 & 0 & 0 \\
\hline Bolivarian Republic of Venezuela & 14 & 69 & 281 & 3 & 21 \\
\hline Costa Rica & 14 & 14 & 14 & 0 & 0 \\
\hline Germany & 14 & 154 & 462 & 0 & 0 \\
\hline Taipei & 14 & 25 & 28 & 11 & 11 \\
\hline Romania & 15 & 34 & 132 & 0 & 0 \\
\hline Croatia & 16 & 42 & 126 & 16 & 48 \\
\hline Australia & 20 & 105 & 427 & 13 & 58 \\
\hline Turkey & 20 & 110 & 871 & 18 & 144 \\
\hline El Salvador & 21 & 22 & 31 & 0 & 0 \\
\hline Panama & 21 & 83 & 174 & 14 & 54 \\
\hline Switzerland & 22 & 118 & 718 & 0 & 0 \\
\hline Canada & 25 & 88 & 570 & 21 & 200 \\
\hline Argentina & 27 & 137 & 697 & 27 & 147 \\
\hline Chile & 28 & 35 & 242 & 0 & 0 \\
\hline Poland & 29 & 34 & 234 & 11 & 66 \\
\hline Philippines & 30 & 110 & 152 & 16 & 16 \\
\hline Brazil & 36 & 66 & 212 & 28 & 64 \\
\hline Israel & 36 & 40 & 60 & 36 & 43 \\
\hline Korea & 36 & 237 & 858 & 35 & 128 \\
\hline Spain & 46 & 221 & 530 & 0 & 0 \\
\hline Indonesia & 59 & 133 & 684 & 0 & 0 \\
\hline Japan & 62 & 213 & 878 & 46 & 248 \\
\hline China & 71 & 90 & 229 & 70 & 166 \\
\hline United States & 81 & 305 & 1494 & 67 & 319 \\
\hline India & 85 & 275 & 720 & 55 & 170 \\
\hline European Union & 175 & 1500 & 7837 & 0 & 0 \\
\hline
\end{tabular}

Source: Authors calculations on STC database, WTO

Note: A maintaining country is defined as a country that applies the SPS measure against which a STC is raised 


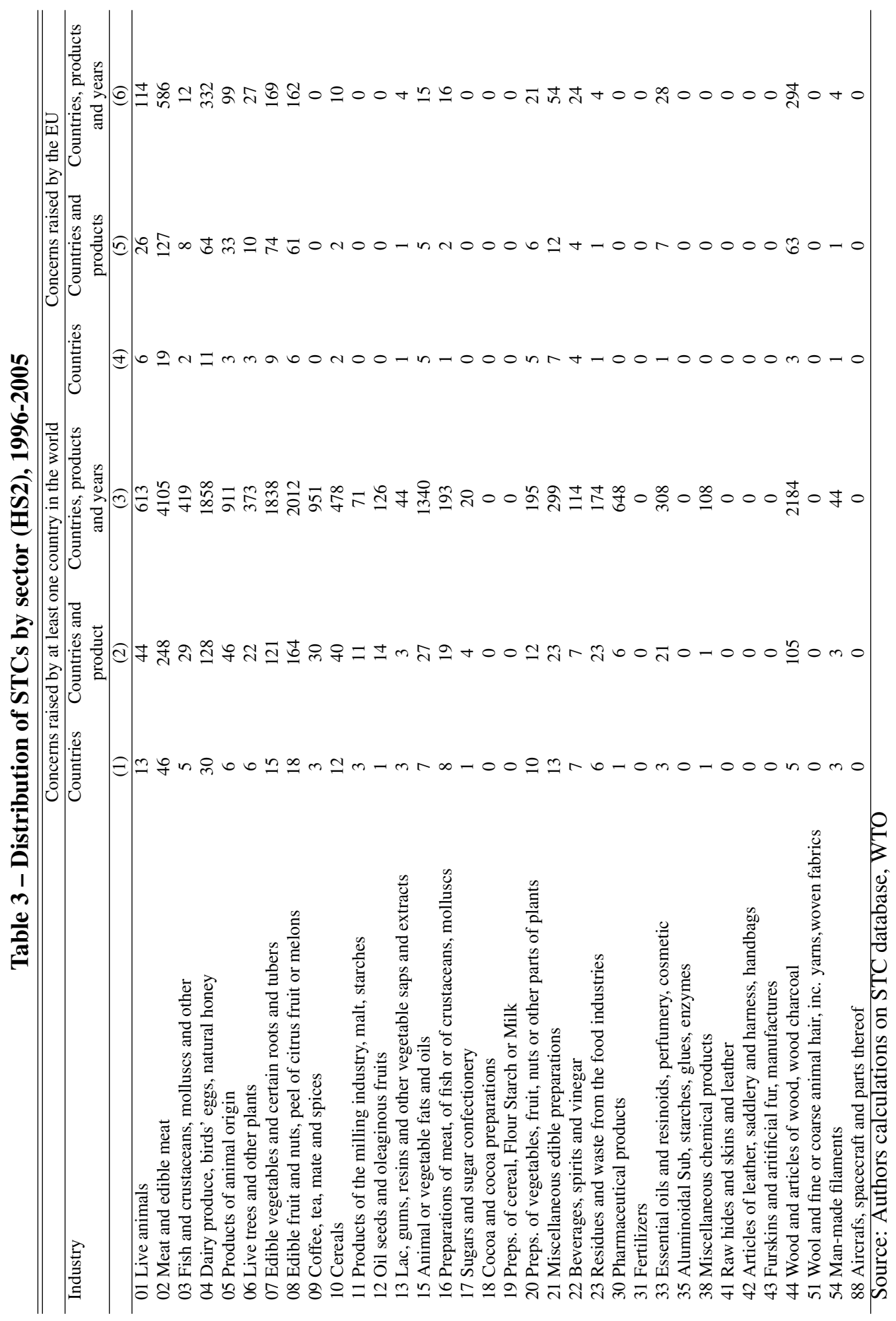




\subsection{French firms export data}

Let's now turn to the export data. Individual export data on French firms are provided by the French Custom for the period 1995-2005. ${ }^{18}$ French firms' dataset includes exports records at firm, product and market level for the universe of French exporters (more precisely exporters located in France). ${ }^{19}$ The dataset classifies product categories using Combined Nomenclature at 8 digits (CN8).

The number of observations is potentially very large: we have for each HS4 heading some 100,000 potential exporters, 200 destinations and 16 years. In order to work with a manageable dataset, we restricted our sample in terms of market destinations. To select relevant markets, we summed exports by destination market over all firms (over sectors and period). For each of this destination specific French export cumulated flow, we computed the median value across destination countries. We restricted our sample to the subsample of destinations above these median values. Descriptive statistics of French firms exports and markets are reported in appendix Table A.1.

Since the EU acts as a single country in WTO committees, we restrict our firm level sample to only extra-EU export flows. We take all but services sectors (98 and 99 in the HS classification) and only firms exporting at least four years within our time span into a certain market/product combination (this reduces the bias of using occasional exporters). The original information on exported products is using the CN8 (an 8-digit European extension of the HS6 comprising some 10,000 product categories). We aggregate this information within some 1,200 headings of the HS4 classification which is also used by the WTO to record the SPS concerns.

Firm level export data (compared with aggregate trade flows data) allow us to properly investigate the effect of NTMs on the intensive/extensive margins of trade, on the exit dynamics from foreign markets and on the price level of exports by French firms. Moreover, it allows us to control for firms' characteristics in determining the effects of NTMs. Indeed large and highly productive firms might react to NTMs differently from small and low productive firms. However, such firm level characteristics must rely on export based measures as we do not have information on turnover, employment or capital for the universe of French exporters. ${ }^{20}$

The relevance of looking at firms characteristics when analysing the impact of SPS measures on trade is also supported by the evidence on the two Kernel distributions of firm sizes in markets where a STC has been raised and in markets where it has not. Figure 4 shows that the distribution of firms' size $^{21}$ is less dispersed and has a larger mean value for firms exporting

\footnotetext{
${ }^{18}$ These data are subject to statistical secrecy.

${ }^{19}$ We consider legal units, as defined by their administrative identifier.

${ }^{20}$ Data on French firms characteristics are available only for firms with more than 25 employees. More than 50 per cent of exporting firms has a number of employees below 20. Therefore, for appropriately account the extensive margin of exports, we do not use data on French firm characteristics.

${ }^{21}$ For the purpose of the figure, size is approximated by total export value by firm.
} 
in markets applying SPS measures subject to concerns than in markets against which no SPSrelated STC has been raised. In fact, the two distributions are statistically different. ${ }^{22}$

\section{Figure 4 - Firm size distribution in presence/absence of SPS}

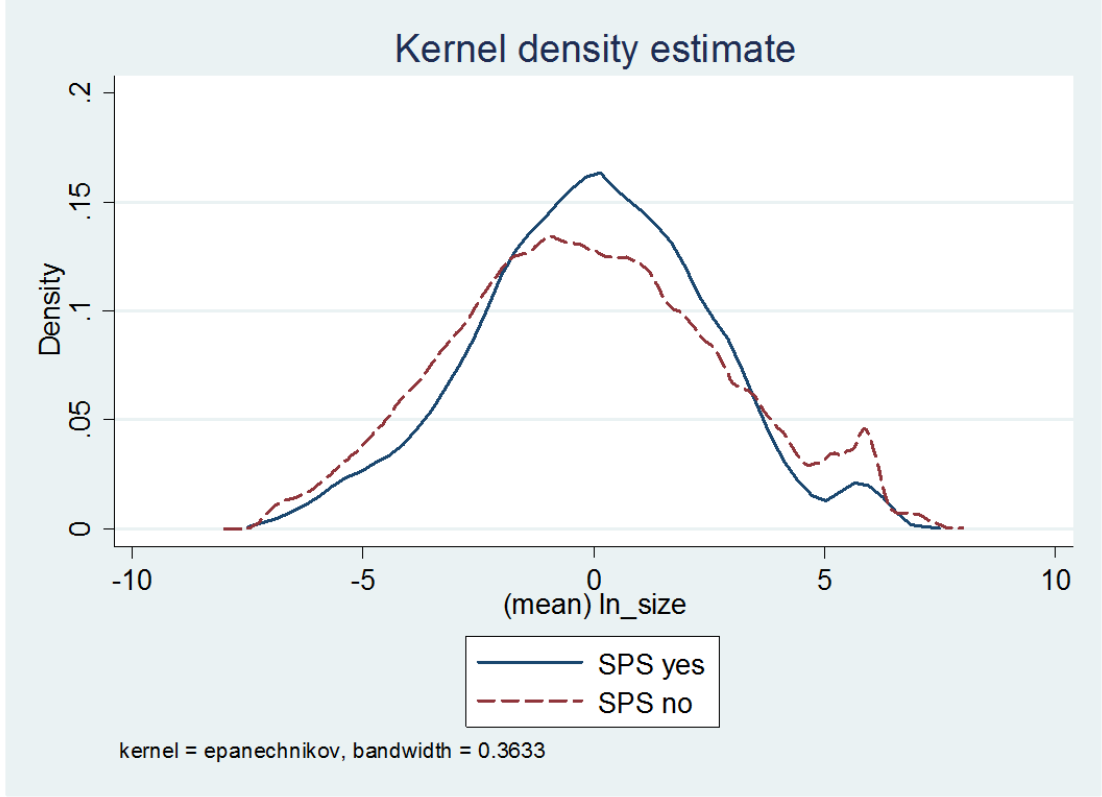

Source: Authors calculations on French Custom Data and STC database, WTO

\section{EMPIRICAL STRATEGY}

We investigate whether the trade impact of non-tariff barriers such as SPS measures is heterogeneous across firms. Our empirical strategy is to explain exporters behaviour - in terms of participation, values shipped and market (price range) positioning, as a function of SPS measures, their joint effect with firm characteristics, and a set of controls including tariffs and the importance of the destination market. Specifically, we estimate the following equation:

$$
\begin{aligned}
y_{i, s, j, t}= & \alpha+\beta_{1} S P S_{s, j, t}+\beta_{2} \ln (\text { size })_{i, t-1}+\beta_{3}\left(S P S_{S, j, t} * \ln (\text { size })_{i, t-1}\right)+\beta_{4} \ln (\text { visibility })_{i, H S 2, j, t-1}+ \\
& \beta_{5}\left(S P S_{S, j, t} * \ln (\text { visibility })_{i, H S 2, j, t-1}\right)+\beta_{6} X_{i, s, j, t}+\phi_{H S 2, t}+\mu_{j, t}+\varepsilon_{i, s, j, t},
\end{aligned}
$$

where subscripts $i, s, j$, and $t$ stand respectively for firm, HS 4 digit product category (or sector 2-digit if HS2), destination country and year. As dependent variables we use (i) a dummy

\footnotetext{
${ }^{22}$ Kolmogorov test null rejected at 99 per cent.
} 
variable for positive trade flows into a certain product-destination market combination to capture the (firm-product) extensive margin of trade, or participation; (ii) a dummy variable indicating whether a firm exits a certain product-market (dummy equal to one if the firm does not export in the current year but exported the year before); (iii) firm's export values (in logs) to capture the intensive margin of trade, ${ }^{23}$ and (iv) the price of exported goods (in logs) proxied by export unit values. ${ }^{24} S P S_{s, j, t}$ represents the existence at time $t$ of an ongoing (unresolved) concern in product $s$ between the EU and an importer country $j$.

Visibility $_{i, H S 2, j, t-1}$ and Size $_{i, t-1}$ are firm-specific characteristics capturing two different dimensions of firms' size. These measures have been lagged by a period to reflect the fact that firms' past performance affects export decisions in the future. ${ }^{25}$ Visibility $_{i, H S 2, j, t-1}$, represents the importance of a firm, in terms of its exports, in a certain sector and destination market. This variable is computed as (the logarithm of one plus) the share of exports of a firm in a certain market and HS2 sector over total French exports in such market and sector. Size $e_{i, t-1}$ represents the overall size of the firm ${ }^{26}$ : the higher the export level the larger the firm.

To investigate whether SPS concerns affect differently heterogeneous exporters, we include an interaction term between firm size measures (described before) and our variable capturing SPS concerns. ${ }^{27}$ Heterogeneous firms trade models ${ }^{28}$ suggest that the effect of an SPS measure on export performance may depend on the size of a firm, provided that size is associated with e.g. productivity and hence with the ability to overcome additional costs to export. In other words, not all firms will be able to cope with the stringency of SPS regulations, which represent a fixed cost of adaptation and/or a variable trade cost.

The set of control variables $X_{s, j, t}$ includes bilateral applied tariffs at product level and a measure of the importance of a given destination market for French firms (MktShare), measured as the (log of one plus) the ratio of sector-destination market specific French exports over total exports in that sector. The latter variable controls for the impact of French exports geographic orientation on the probability to raise a concern: given that SPS measures might be imposed by

\footnotetext{
${ }^{23}$ In this regression the dependent variable includes only positive trade values.

${ }^{24}$ Despite the dichotomous nature of some of our dependent variables (extensive margin and exit of firms), we prefer to rely on simple linear OLS estimator rather than a non-linear probit (or logit). This because non-linear models suffer from incidental parameter problem when a big set of fixed effects are included in the regressions. OLS estimates provide a reasonable direct estimate of the sample average marginal effect. However, we also run non linear models (logit) for regressions on the extensive margin of trade and firm exit probability; results, available under request, are robust.

${ }^{25}$ Since we do not have information on French exporters balance sheets, we calculate size variables in terms of exports and not in terms of total sales. The empirical literature has extensively shown that export values are a good proxy of the overall size of the firm: big exporters are usually larger and more efficient firms than non exporters (see Mayer and Ottaviano 2007).

${ }^{26} \ln (\text { size })_{i, t-1}=\sum_{s \subset S} \sum_{j \subset J}$ export $_{i, s, j, t-1}$

${ }^{27}$ To increase the interpretability of the interaction terms, both Visibility and Size have been centered (e.g. computed as difference from their median value).

${ }^{28}$ Melitz (2003) and Melitz and Ottaviano (2008).
} 
foreign countries to prevent imports from European countries other than France, some measures might be irrelevant for French firms, simply because the imposing country is not important for French exports. This might bias our SPS coefficients downwards. To further control for this bias we also include as a control the interaction between the Market share and the SPS variable. Finally, $\phi_{H S 2, t}$ and $\mu_{j, t}$ represent sector-time and country-time fixed effects and control respectively for sector specific shocks common to all countries and country specific business cycles.

\section{RESUlts}

\subsection{SPS and the extensive margin of trade}

Results on the impact of SPS measures on export participation are reported in Table 4. After controlling for tariffs, the variable SPS has a negative and significant impact on the extensive margin of trade. Specifically, the imposition of an SPS measure in a certain product decreases the probability of exporting such product by approximately 2 percent. This result confirms our expectations: restrictive SPS measures act as an additional cost on foreign markets and increase the productivity threshold for export participation. Notice that the coefficient on tariffs tends to be not significant, confirming that in terms of the decision to enter a certain export market, fixed costs to export are more important than variable costs of exports, such as tariffs. ${ }^{29}$ Therefore, in these regressions our SPS variable might be capturing the fixed costs component of such measures.

In columns (2) to (4), we include in the regressions firm level characteristics and their interaction with SPS measures. Being large or highly visible is associated with a high probability to export. This result is in line with the heterogeneous firms trade theory. In addition, big players may remain in the market where the restrictive measure has been imposed and take advantage of the reduced competition in such market. This may be because big firms are able to move resources from unaffected product-markets to the SPS imposing product-market or because they are more productive, and therefore they may more easily overcome the fixed or variable cost of an SPS. This is what we find in column (2) where the interaction between total firm's exports (Firm size) and the SPS dummy has a positive and significant coefficient: the larger the size of the exporter the lower the effect of a SPS concern (the average effect of SPS remains negative since the coefficient on SPS dummy is bigger than the one on the interacted variable). In contrast, the interaction between Firm Visibility and SPS is not significant, meaning that the negative impact of SPS measures on the probability to export does not vary across firms with different levels of visibility (see column (3)).

In column (4), the two different measures of firm size and their respective interactions with the SPS variable are contemporaneously included in the regression. Results confirm that the

\footnotetext{
${ }^{29}$ See Chaney (2008)
} 
Table 4 - Extensive margin estimation - OLS

\begin{tabular}{lccccc}
\hline \hline & $(1)$ & $(2)$ & $(3)$ & $(4)$ & $(5)$ \\
\hline SPS & $-0.015^{* * * *}$ & $-0.026^{* * *}$ & $-0.017 * * *$ & $-0.024 * * *$ & $-0.032^{* * *}$ \\
& $(0.004)$ & $(0.005)$ & $(0.005)$ & $(0.005)$ & $(0.007)$ \\
Firm Size (lag) & & $0.040^{* * *}$ & & $0.035^{* * *}$ & $0.035^{* * *}$ \\
& & $(0.000)$ & & $(0.000)$ & $(0.000)$ \\
Firm Size (lag)*SPS & & $0.013^{* * *}$ & & $0.011^{* * *}$ & $0.010^{* * *}$ \\
& & $(0.003)$ & & $(0.003)$ & $(0.003)$ \\
Firm Visibility (lag) & & $1.049 * * *$ & $0.757 * * *$ & $0.763 * *$ \\
& & $(0.007)$ & $(0.007)$ & $(0.007)$ \\
Firm Visibility (lag)*SPS & & 0.063 & 0.102 & $0.135^{*}$ \\
& & & $(0.078)$ & $(0.077)$ & $(0.077)$ \\
Mkt Share (lag) & & & & $0.092^{* * *}$ \\
& & & & & $(0.004)$ \\
Mkt Share (lag)*SPS & & & & & $(0.033)$ \\
& & & & & $0.075^{* *}$ \\
Tariff (in ln) & $-0.014 * * *$ & -0.000 & -0.000 & 0.002 & 0.000 \\
& $(0.004)$ & $(0.004)$ & $(0.004)$ & $(0.004)$ & $(0.004)$ \\
\hline Observations & 1818220 & 1636167 & 1636167 & 1636167 & 1636167 \\
R-squared & 0.033 & 0.045 & 0.037 & 0.050 & 0.050 \\
\hline
\end{tabular}

Note: all estimations include year-destination market and year-sector (HS2) fixed effects.

Robust standard errors in parentheses. *** $p<0,01 ; * * p<0,05 ; * p<0,1$.

negative impact of SPS measures is dampened for large firms, while being highly visible in a given sector-market does not affect the impact of SPS measures.

In column (5), we also control for the importance of a given destination country for French exporters - Mkt share and its interaction with the SPS variable. In general, our main results are robust to the inclusion of such controls. ${ }^{30}$ In addition, a positive and significant coefficient on the Market Share variable can be interpreted both from the supply or the demand side of the firm. In the first case, markets where French exports are significant may be characterised by lower search costs associated with export transactions -including activities such as market research and country regulations for new exporters, and this may encourage entry; in the second case, new firms are more likely to enter those markets where there is already a high demand for French exports. Finally, the coefficient associated to the interaction between Market Share and SPS dummy is positive and significant, meaning that the imposition of an SPS measure has a lower effect for destination markets which are important for France (see column (5)).

As a second step, we analyze the extensive margin of trade from the perspective of firm exit decisions. In particular, we investigate whether SPS measures increase the probability of exit for exporting firms. This can be because either the exporters cannot pay the fixed cost of adaptation to the new SPS, or they reorient their exports (towards a third market) as the marginal

\footnotetext{
${ }^{30}$ In column (5) the interaction term between firm visibility and SPS becomes significant. However, this coefficient is only significant at the 10 percent level and it loses significance once we control for endogeneity (see Table 9).
} 
Table 5 - Exit probability estimation - OLS

\begin{tabular}{|c|c|c|c|c|c|}
\hline & (1) & (2) & (3) & (4) & (5) \\
\hline \multirow[t]{2}{*}{ SPS } & $0.014 * * *$ & $0.019 * * *$ & $0.014 * * *$ & $0.019 * * *$ & $0.027 * * *$ \\
\hline & $(0.003)$ & $(0.004)$ & $(0.003)$ & $(0.004)$ & $(0.005)$ \\
\hline \multirow[t]{2}{*}{ Firm Size (lag) } & & $-0.002 * * *$ & & $-0.001 * * *$ & $-0.001 * * *$ \\
\hline & & $(0.000)$ & & $(0.000)$ & $(0.000)$ \\
\hline \multirow[t]{2}{*}{ Firm Size (lag)*SPS } & & $-0.007 * * *$ & & $-0.006^{* *}$ & $-0.006^{* *}$ \\
\hline & & $(0.002)$ & & $(0.002)$ & $(0.002)$ \\
\hline \multirow[t]{2}{*}{ Firm Visibility (lag) } & & & $-0.193 * * *$ & $-0.178 * * *$ & $-0.181 * * *$ \\
\hline & & & $(0.004)$ & $(0.005)$ & $(0.005)$ \\
\hline \multirow[t]{2}{*}{ Firm Visibility (lag)*SPS } & & & -0.062 & -0.029 & -0.049 \\
\hline & & & $(0.053)$ & $(0.056)$ & $(0.056)$ \\
\hline \multirow[t]{2}{*}{ Mkt Share (lag) } & & & & & $-0.042 * * *$ \\
\hline & & & & & $(0.003)$ \\
\hline \multirow[t]{2}{*}{ Mkt Share (lag)*SPS } & & & & & $-0.068 * * *$ \\
\hline & & & & & $(0.024)$ \\
\hline \multirow[t]{2}{*}{ Tariff (in $\ln$ ) } & 0.0003 & -0.000 & -0.001 & -0.001 & -0.000 \\
\hline & $(0.003)$ & $(0.003)$ & $(0.003)$ & $(0.003)$ & $(0.003)$ \\
\hline Observations & 1818220 & 1636167 & 1636167 & 1636167 & 1636167 \\
\hline R-squared & 0.010 & 0.008 & 0.009 & 0.009 & 0.0099 \\
\hline
\end{tabular}

cost of exporting to the destination imposing the SPS has increased. Importantly, note that firm exit does not mean that firms stop exporting in general; they only stop exporting to the marketproduct where the SPS measure has been imposed. Results are reported in Table 5. The positive and significant coefficient on the SPS variable confirms that SPS measures increase the probability for firms to exit. In particular, the imposition of an SPS in a certain market increases the probability of exit such market by 2 percentage points on average. Also in this case, large firms are less likely than small firms to exit a market after the imposition of an SPS measure.

\subsection{SPS and the intensive margin of trade}

Next, we examine the impact of SPS concerns on firms' export values. Results, reported in Table 6, show that SPS measures negatively affect the intensive margin of trade. In columns (3) and (3) of Table 6, the coefficient on the SPS variable is not significant. This might be driven by the fact that large firms are not strongly affected by SPS restrictive measures. In fact, when we assess the differential impact of SPS measures across firms with different sizes, whilst the SPS coefficient is negative and significant for small firms, for large firms the negative impact is very small (see columns (2) and (4)). As discussed for the outcomes on the extensive margin, the intuition for this result is that large exporters, given their wide portfolio of destinationsectors are able to move resources toward the SPS imposing product-market, overcome the cost and enjoy the lower competition in that market. When we control for the importance of the destination market for French exporters and its interaction with SPS measures, having 
Table 6 - Intensive margin estimation - OLS

\begin{tabular}{|c|c|c|c|c|c|}
\hline & (1) & (2) & (3) & (4) & (5) \\
\hline SPS & $\begin{array}{c}-0.038 \\
(0.026)\end{array}$ & $\begin{array}{c}-0.136 * * * \\
(0.027)\end{array}$ & $\begin{array}{c}-0.008 \\
(0.026)\end{array}$ & $\begin{array}{c}-0.097 * * * \\
(0.06)\end{array}$ & $\begin{array}{c}-0.221 * * * \\
(0.034)\end{array}$ \\
\hline Firm Size (lag) & & $\begin{array}{c}0.286 * * * \\
(0.001)\end{array}$ & & $\begin{array}{c}0.215 * * * \\
(0.001)\end{array}$ & $\begin{array}{c}0.216 * * * \\
(0.001)\end{array}$ \\
\hline Firm Size (lag)*SPS & & $\begin{array}{c}0.131 * * * \\
(0.023)\end{array}$ & & $\begin{array}{c}0.108 * * * \\
(0.021)\end{array}$ & $\begin{array}{c}0.0959 * * * \\
(0.022)\end{array}$ \\
\hline Firm Visibility (lag) & & & $\begin{array}{c}11.40 * * * \\
(0.068)\end{array}$ & $\begin{array}{c}9.718 * * * \\
(0.064)\end{array}$ & $\begin{array}{c}9.919 * * * \\
(0.064)\end{array}$ \\
\hline Firm Visibility (lag)*SPS & & & $\begin{array}{l}-0.286 \\
(0.765)\end{array}$ & $\begin{array}{l}-0.331 \\
(0.711)\end{array}$ & $\begin{array}{c}0.665 \\
(0.710)\end{array}$ \\
\hline Mkt Share (lag) & & & & & $\begin{array}{c}2.529 * * * \\
(0.023)\end{array}$ \\
\hline Mkt Share (lag)*SPS & & & & & $\begin{array}{c}1.329 * * * \\
(0.193)\end{array}$ \\
\hline Tariff (in ln) & $\begin{array}{c}-0.095^{* * *} * \\
(0.025)\end{array}$ & $\begin{array}{l}-0.035 \\
(0.024)\end{array}$ & $\begin{array}{c}0.008 \\
(0.024)\end{array}$ & $\begin{array}{c}0.032 \\
(0.024)\end{array}$ & $\begin{array}{l}-0.035 \\
(0.024)\end{array}$ \\
\hline Observations & 1246603 & 1142191 & 1142191 & 1142191 & 1142191 \\
\hline R-squared & 0.062 & 0.108 & 0.130 & 0.163 & 0.163 \\
\hline
\end{tabular}

restrictive SPS measures reduces trade values by 22 per cent for the median firm. Also in this case the additional trade cost that SPS measures represent on the intensive margin of exports is attenuated for large firms (see column (5)). Notice that the coefficient associated with the SPS measures are larger in this last regression, compared with the previous columns, which confirms the fact that when we do not control for measures that might be irrelevant for French exports in the regressions, our estimation on the impact of SPS measures on the intensive margin of trade might be downward biased.

\subsection{SPS and firms' pricing}

In any strategic interaction framework, imposing a barrier to entry leads to a redistribution of market shares among players and to a strategic response in terms of pricing. Under imperfect competition, the rent (higher price, lower quantities) created by the new barrier to entry is subject to distribution among agents (exporters versus domestic firms). Firms may well make decisions in order to capture part of this rent. This kind of response has been extensively documented in the case of voluntary export restrictions - VERs (Krishna, 1989). In such a framework, we expect upgrading by the survivors, and a higher price paid by the consumer on the destination market imposing a stringent SPS. We face the former question by estimating the effect of SPS concerns on trade unit values (a loose proxy of price). Results, reported in Table 7 confirm a positive effect of SPS concerns on the unit value of firms' exports. It means that SPS is an incentive for firms to increase the price of their exported goods. Unexpectedly, this is 
Table 7 - Trade Unit Values estimation - OLS

\begin{tabular}{|c|c|c|c|c|c|}
\hline & (1) & (2) & (3) & (4) & (5) \\
\hline \multirow[t]{2}{*}{ SPS } & $0.414 * * *$ & $0.481 * * *$ & $0.430 * * *$ & $0.476 * * *$ & $0.0770 * * *$ \\
\hline & $(0.0177)$ & $(0.0207)$ & $(0.0187)$ & $(0.0207)$ & $(0.0251)$ \\
\hline \multirow[t]{2}{*}{ Firm Size (lag) } & & $0.063 * * *$ & & $0.075 * * *$ & $0.075 * * *$ \\
\hline & & $(0.001)$ & & $(0.001)$ & $(0.001)$ \\
\hline \multirow[t]{2}{*}{ Firm Size (lag)*SPS } & & $-0.074 * * *$ & & $-0.068 * * *$ & $-0.058 * * *$ \\
\hline & & $(0.013)$ & & $(0.014)$ & $(0.013)$ \\
\hline \multirow[t]{2}{*}{ Firm Visibility (lag) } & & & $-1.147 * * *$ & $-1.741 * * *$ & $-1.783 * * *$ \\
\hline & & & $(0.032)$ & $(0.033)$ & $(0.033)$ \\
\hline \multirow[t]{2}{*}{ Firm Visibility (lag)*SPS } & & & $-0.709 * *$ & -0.139 & 0.224 \\
\hline & & & $(0.287)$ & $(0.305)$ & $(0.312)$ \\
\hline \multirow[t]{2}{*}{ Mkt Share (lag) } & & & & & $-0.504 * * *$ \\
\hline & & & & & $(0.018)$ \\
\hline \multirow[t]{2}{*}{ Mkt Share (lag)*SPS } & & & & & $2.742 * * *$ \\
\hline & & & & & $(0.135)$ \\
\hline \multirow[t]{2}{*}{ Tariff (in ln) } & $-0.516 * * *$ & $-0.488 * * *$ & $-0.510 * * *$ & $-0.501 * * *$ & $-0.472 * * *$ \\
\hline & $(0.016)$ & $(0.017)$ & $(0.017)$ & $(0.017)$ & $(0.017)$ \\
\hline Observations & 1246603 & 1142191 & 1142191 & 1142191 & 1142191 \\
\hline R-squared & 0.447 & 0.448 & 0.447 & 0.450 & 0.450 \\
\hline
\end{tabular}

Note: all estimations include year-destination market and year-sector (HS2) fixed effects.

Robust standard errors in parentheses. $* * * p<0,01 ; * * p<0,05 ; * p<0,1$.

not true for large players. This is particularly clear in columns (2) to (5) of Table 7. We verify in these columns that large players sell at cheaper prices and upgrade less than small firms in presence of SPS. ${ }^{31}$

The coefficient on tariffs is negative and significant in all regressions. One possible explanation of this counterintuitive result is that in this specification tariffs are endogenous: the political economy literature on tariff protection shows that homogeneous goods - goods in low value added sectors such as agriculture - tend to be more protected than differentiated goods. The fact that lower prices are a determinant of high levels of protection (e.g. high tariffs) can explain why a decrease in tariffs is positively correlated with trade unit values.

\footnotetext{
${ }^{31}$ The former result can also be driven by a reduction in exported quantities. In fact, we find robust evidence of the detrimental effect of SPS on the quantities exported by firms and we also confirm the result that big exporters suffer the negative effect of SPS to a lesser extent than small players (results are available under request).
} 


\subsection{Endogeneity}

Equation (1) may be subject to endogeneity of SPS concerns due to both omitted variables bias and reverse causality. The omitted variable bias is strongly reduced by the inclusion of a wide range of fixed effects controlling for most of the potential variables affecting export behaviour by firms. In addition, the inclusion in our regression of variables such as Size and Visibility captures the impact of firm specific variables on export performance (Mayer and Ottaviano 2007). ${ }^{32}$

Reverse causality arises if the government of a certain destination market introduces a SPS measure in response to high levels of French imports (from a specific French firm or from a group of firms) and a concern is raised by the EU against this measure. The fact that we are focusing on firm level estimations and that we are analyzing the differential impact of SPS measures across firms with different sizes, reduces significantly reverse causality. Reverse causality can still arise at the level of the firm for two reasons. One is that a country might be more likely to impose a protectionist measure against firms that have a large share of their domestic market (that is, firms with high visibility). In addition, given that firms with high visibility in a destination market are more likely to be targeted by protectionist SPS measures, they are also more likely to lobby their governments to raise a concern related with such measures at the WTO. Our findings do not support such fears: the interaction with the measure of firms' visibility and SPS measures is not significant, confirming that this is not the main motivation of the concern.

However, as a robustness check, we estimate our regressions lagging the SPS variables by one year: given that a concern raised in $t-1$ is related to a measure introduced in $t-2$ or earlier, there is low chance that such concern would be driven by exports at time $t .^{33}$ Table 8 shows that the results on the impact of SPS measures on different dimensions of export behaviors are in line with our baseline regressions. In particular, the imposition of SPS measures has a negative impact on both the intensive and extensive margins of trade. Such impact is attenuated for big exporters. In addition, results confirm that due to product upgrading, consumers in SPS imposing markets face higher prices.

\footnotetext{
${ }^{32}$ For computational reasons it was not possible to include firm-level fixed effects in our regressions.

${ }^{33}$ In the case of new measures, the variable SPS computed at $t-1$ will capture the contemporaneous effect of an SPS measure on trade: it takes around 8 months for this measures to enter into force. To control for this we run all regressions calculating the SPS variable at $t-2$. Results, available under request, remain robust.
} 


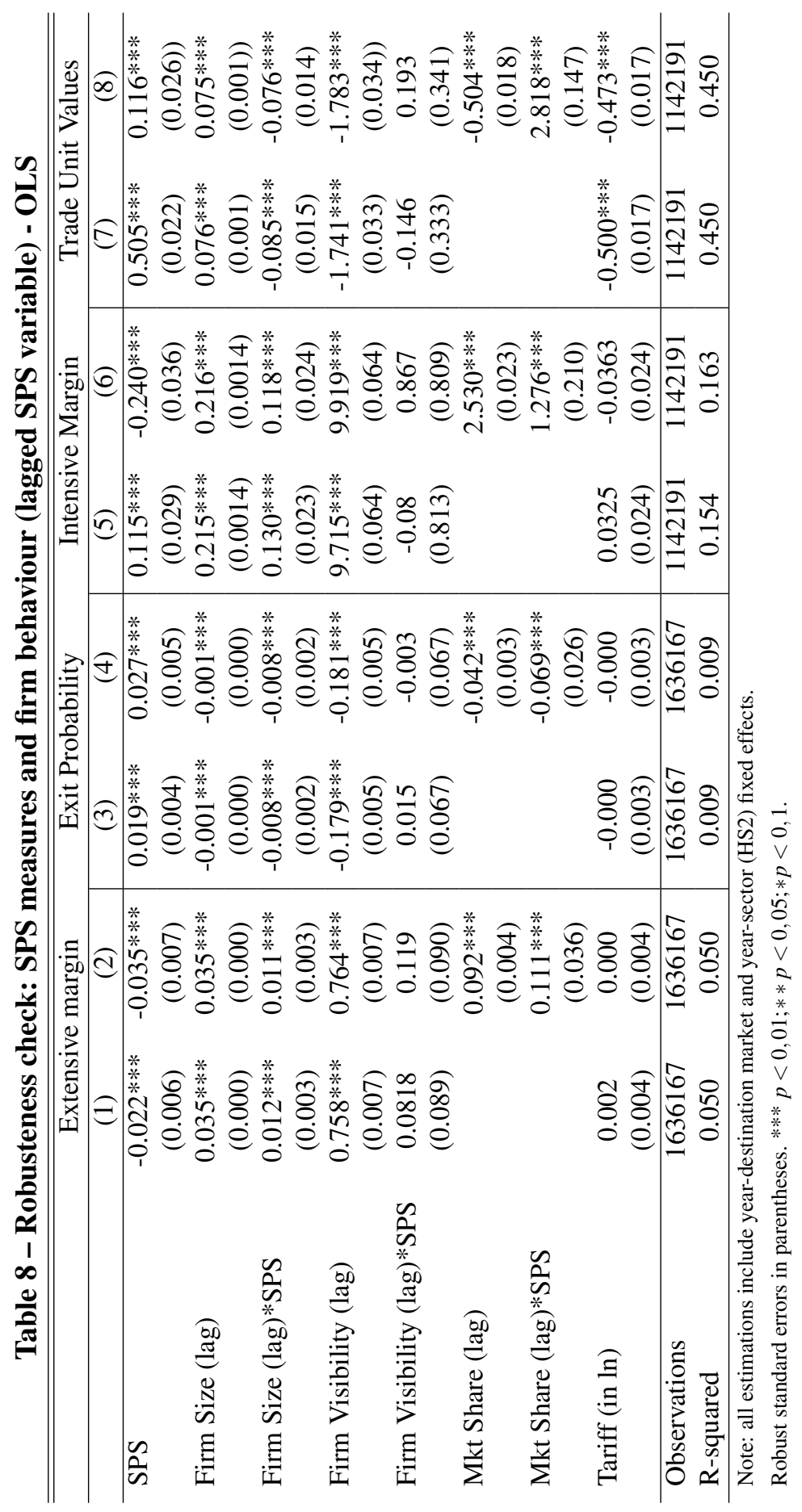


As a second strategy to address the endogeneity bias, we follow an instrumental variables (IV) approach to estimate specification (1). In particular, we generate two instruments for the SPS variable. The first instrument is the overall number of concerns that have been raised against country $j$ by exporters other than the EU (and therefore France) in a certain product $k$ (SPSexcl.EU $\left.U_{s, j, t-1}\right)$. The idea is that standards such as SPS measures are non- discriminatory domestic regulations. Therefore, even if some measures were not specifically raised as concerns by French exporters, they still have an impact on French exports. As a second instrument we use the total number of concerns raised in a certain HS3 sector (excluding the concern raised at the product level)-SPSHS3. The intuition behind this instrument is that if there is an SPS on a certain product $s$, it is highly probable that an SPS concern will be raised in products similar to $s$, that is products within the same industry HS3. ${ }^{34}$

The results from the first stage regression of the IV specification using as instrument the number of concerns raised within an HS3 and the number of concerns raised by countries other than the EU are presented in Table 9. The outcomes suggest that, in general, both our instruments are good predictors for the SPS variable. In addition, the F-statistic of the regressions indicate that none of our instruments are not weak. Second stage results for the extensive margin of trade are presented in Table 10. Independently of the instrument used, the impact of SPS measures on firm export decisions (either participation or exit) is still negative and significant. This effect is usually dampened for large firms and sometimes even reversed. With respect to the impact of SPS measures on the intensive margin of trade and on trade unit values, the second stage results using as instrument the total number of concerns raised by exporters other than the EU are in line with our baseline regression and confirm the fact that SPS restrictive measures decrease firm export values and lead to higher prices in the imposing countries (see Table 11). Again, large firms increase prices less than small firms. However, the interaction between SPS and large firms is not significant in the extensive margin regression. The results we obtain using the number of SPS concerns within an HS3 industry as instrument are mixed. Whilst the impact on export values is in line with our baseline regressions, the impact of SPS measures on trade unit values has the opposite sign.

\footnotetext{
${ }^{34}$ This instrument could still be endogenous if large exporters export a lot of similar products within a certain HS3. However, in our sample the share of firms exporting more that one product within the same HS3 to a certain destination market is very low (less than 4 percent).
} 

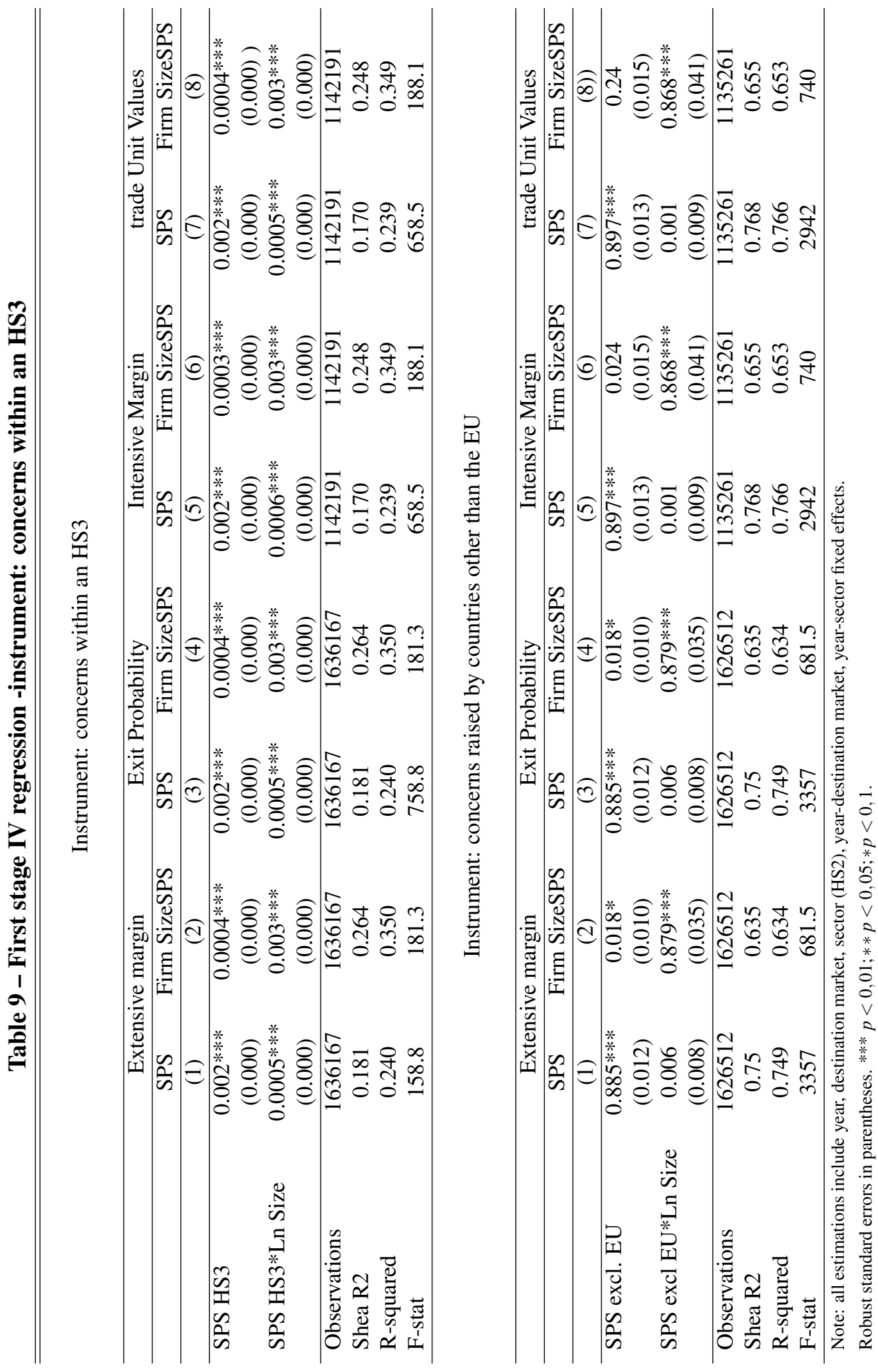

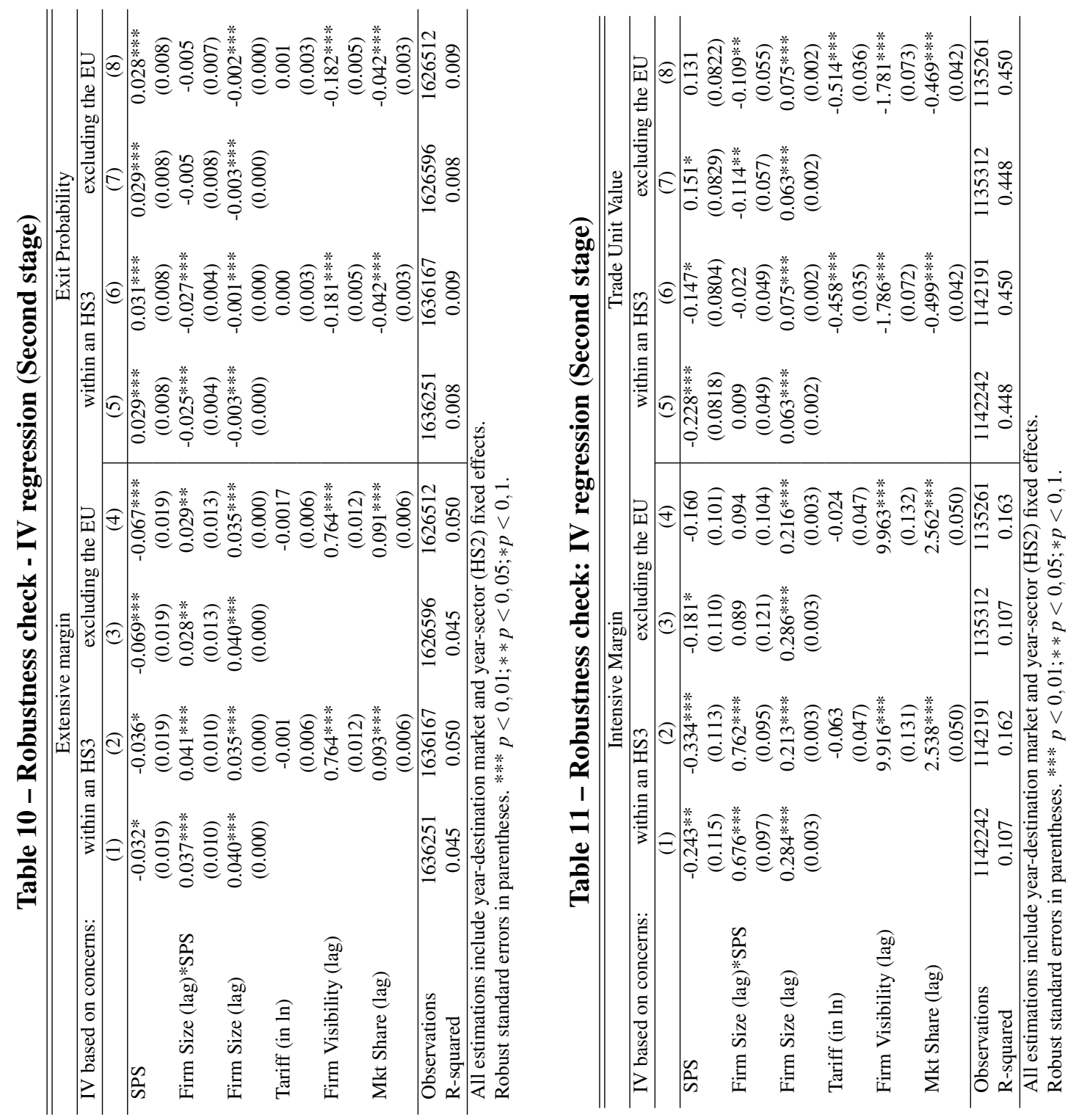


\section{Conclusion}

This paper studies the trade effects of restrictive SPS measures using a panel of French firmlevel exports over the period 1995-2005 and an original dataset on SPS specific trade concerns raised at the WTO. The advantage of using this dataset is that it only includes SPS measures that are perceived as a possible obstacle to trade by the exporter, thus overcoming one of the problems with non-tariff measures previously used in the economic literature that failed to distinguish between restrictive and possibly trade-enhancing measures.

Our paper contributes to the existing literature on the trade impact of SPS measures also through the analysis of several dimensions of firm's trade performance. We estimate the effect of introducing an SPS measure in a certain market and product on both the intensive and extensive margins of trade. We also study the effect of SPS on trade unit values and exit probability. Most importantly, our analysis accounts for a differentiated impact of SPS measures on several dimensions of trade across firms. In addition, we pay particular attention to the potential endogeneity of the measure.

Our results show that the imposition of SPS measures reduces the participation of firms in export markets. This negative effect is attenuated for big exporters. Our interpretation is that, big players exporting in several sector-markets, having resources to move from unaffected to SPS affected market, are able to cope with the SPS imposition and might enjoy the reduced competition in the SPS imposing market. The latter effect is supported by estimations on the intensive margin of trade. The value of exports (by exporting firms) is deterred by the presence of SPS concerns, but it is increased for big exporters. We also find overwhelming evidence of a price increasing effect of SPS imposition. SPS represents an incentive for firms to increase their price range positioning in a certain destination market. This effect is stronger the higher the importance of the destination market for French exports.

Overall, our results show that the effects of SPS measures on trade are complex. SPS measures do not just reduce existing trade flows. They also affect market participation and price range positioning. Moreover, the effect of SPS measures strictly depends on firms' characteristics.

Our results have important implications from a policy perspective. The significant impact of non-tariff barriers such as SPS measures on trade highlights the challenges faced by countries at the multilateral and regional levels to negotiate disciplines on domestic regulations to complement their commitments on tariffs. Our results also illustrate the fact that governments willing to cooperate on non-tariff measures integration should take into account the importance of the fixed cost component of trade costs in such measures, and therefore their redistribution effect on investment between small and large firms. 


\section{REFERENCES}

Baldwin, R. (2001). Regulatory Protectionism, Developing Nations and a Two-Tier World Trade System. CEPR discussion paper n.2574.

Chaney, T. (2008), Distorted Gravity: the Intensive and Extensive Margins of International Trade, American Economic Review 98(4): 1707-1721.

Chen, M.X, T. Otsuki and J.S. Wilson. (2006). Do Standards Matter for Export Success. World Bank Research Working Paper 3809.

De Sousa, J., T. Mayer and S. Zignago. (2011). Market access in global and regional trade. Regional Science and Urban Economics, forthcoming.

Disdier A.-C., L. Fontagné and M. Mimouni. (2008), The Impact of Regulations on Agricultural Trade: Evidence from SPS and TBT Agreements. American Journal of Agricultural Economics, 90(2): 336-350.

Fontagné L., M. Mimouni and J.M. Pasteels. (2005-a), Estimating the Impact of Environmental SPS and TBT on International Trade. Integration and Trade, (22): 7-37.

Fontagné L., F. von Kirchbach and M. Mimouni. (2005-b), An Assessment of EnvironmentallyRelated Non-Tariff Measures. The World Economy, 28 (10): 1417-1439.

Kee H.L., Nicita A. and M. Olarreaga. (2009), Estimating Trade Restrictiveness Indices. Economic Journal, 119 (534):172-199.

Krishna K. (1989). Trade restrictions as facilitating practices. Journal of International Economics, 26(3-4): 251-270.

Mayer, T. and G.I. Ottaviano. (2007). Happy few: the internationalisation of European firms New facts based on firm-level evidence. Bruegel Blueprints.

Melitz, M. (2003). The Impact of Trade on Intra-Industry Reallocations and Aggregate Industry Productivity. Econometrica, 71(6): 1695-1725.

Melitz, M. and G.I.P. Ottaviano (2008). Market Size, Trade, and Productivity. Review of Economic Studies, vol. 75(1), pages 295-316, 01.

Moenius, J. (2004). Information versus Product Adaptation: The Role of Standards in Trade. International Business and Markets Research Center Working Paper, Northwestern University.

Reyes, J.D. (2011). International harmonization of product standards and firm heterogeneity in international trade. Policy Research Working Paper Series 5677, The World Bank. 


\section{APPENDIX}

Table A1: Descriptive statistics of French Firms by HS2 chapter, 1996 and 2005

\begin{tabular}{|c|c|c|c|c|c|c|}
\hline \multirow[b]{2}{*}{ Chapter } & \multicolumn{3}{|c|}{ year 1996} & \multicolumn{3}{|c|}{ year 2005} \\
\hline & $\begin{array}{l}\text { Average exports } \\
\text { by firm (in mil.) }\end{array}$ & $\begin{array}{c}\text { Number of } \\
\text { markets }\end{array}$ & $\begin{array}{l}\text { Number of } \\
\text { exporters }\end{array}$ & $\begin{array}{l}\text { Average exports } \\
\text { by firm (in mil.) }\end{array}$ & $\begin{array}{c}\text { Number of } \\
\text { markets }\end{array}$ & $\begin{array}{c}\text { Number of } \\
\text { exporters }\end{array}$ \\
\hline 1 & 0.38 & 15 & 84 & 0.46 & 14 & 89 \\
\hline 2 & 0.79 & 13 & 153 & 1.10 & 14 & 127 \\
\hline 3 & 0.15 & 14 & 152 & 0.30 & 13 & 113 \\
\hline 4 & 1.15 & 15 & 184 & 1.58 & 15 & 180 \\
\hline 5 & 0.37 & 13 & 34 & 0.76 & 12 & 36 \\
\hline 6 & 0.06 & 13 & 125 & 0.07 & 12 & 129 \\
\hline 7 & 0.18 & 14 & 202 & 0.24 & 15 & 204 \\
\hline 8 & 0.21 & 14 & 211 & 0.34 & 15 & 216 \\
\hline 9 & 0.40 & 14 & 79 & 0.31 & 13 & 84 \\
\hline 10 & 2.52 & 9 & 47 & 6.85 & 10 & 46 \\
\hline 11 & 1.42 & 15 & 32 & 1.39 & 15 & 39 \\
\hline 12 & 0.17 & 13 & 143 & 0.23 & 15 & 148 \\
\hline 13 & 0.27 & 15 & 90 & 0.47 & 15 & 120 \\
\hline 14 & 0.10 & 7 & 15 & 0.01 & 3 & 12 \\
\hline 15 & 0.44 & 15 & 89 & 0.15 & 15 & 99 \\
\hline 16 & 0.34 & 15 & 137 & 0.11 & 14 & 127 \\
\hline 17 & 0.51 & 15 & 118 & 0.62 & 15 & 115 \\
\hline 18 & 0.20 & 13 & 98 & 0.56 & 15 & 102 \\
\hline 19 & 0.29 & 15 & 253 & 0.37 & 15 & 283 \\
\hline 20 & 0.15 & 14 & 216 & 0.25 & 15 & 214 \\
\hline 21 & 0.34 & 15 & 323 & 0.36 & 15 & 345 \\
\hline 22 & 0.51 & 15 & 2627 & 0.75 & 15 & 3271 \\
\hline 23 & 0.50 & 15 & 78 & 0.78 & 15 & 84 \\
\hline 24 & 2.34 & 12 & 8 & 6.47 & 14 & 8 \\
\hline 25 & 0.20 & 15 & 274 & 0.27 & 15 & 246 \\
\hline 26 & 0.11 & 3 & 19 & 0.40 & 7 & 22 \\
\hline 27 & 3.37 & 15 & 98 & 13.55 & 15 & 86 \\
\hline 28 & 2.20 & 15 & 167 & 2.79 & 15 & 187 \\
\hline 29 & 2.89 & 15 & 313 & 3.32 & 15 & 308 \\
\hline 30 & 1.99 & 15 & 266 & 10.63 & 15 & 261 \\
\hline 31 & 0.28 & 9 & 47 & 0.23 & 10 & 42 \\
\hline 32 & 0.36 & 15 & 340 & 0.67 & 15 & 356 \\
\hline 33 & 1.15 & 15 & 792 & 1.82 & 15 & 828 \\
\hline 34 & 0.21 & 15 & 335 & 0.28 & 15 & 356 \\
\hline 35 & 0.55 & 15 & 137 & 0.83 & 15 & 152 \\
\hline 36 & 0.21 & 15 & 25 & 0.27 & 14 & 29 \\
\hline 37 & 0.33 & 15 & 116 & 0.51 & 15 & 93 \\
\hline 38 & 0.52 & 15 & 503 & 1.06 & 15 & 545 \\
\hline 39 & 0.26 & 15 & 1838 & 0.47 & 15 & 2065 \\
\hline 40 & 0.71 & 15 & 346 & 1.11 & 15 & 332 \\
\hline 41 & 0.46 & 15 & 158 & 0.32 & 15 & 139 \\
\hline 42 & 0.79 & 15 & 522 & 1.88 & 15 & 524 \\
\hline 43 & 0.23 & 9 & 41 & 0.12 & 9 & 47 \\
\hline 44 & 0.15 & 14 & 700 & 0.23 & 15 & 646 \\
\hline
\end{tabular}




\begin{tabular}{|c|c|c|c|c|c|c|}
\hline \multirow[b]{2}{*}{ Chapter } & \multicolumn{3}{|c|}{ year 1996} & \multicolumn{3}{|c|}{ year 2005} \\
\hline & $\begin{array}{l}\text { Average exports } \\
\text { by firm (in mil.) }\end{array}$ & $\begin{array}{c}\text { Number of } \\
\text { markets }\end{array}$ & $\begin{array}{l}\text { Number of } \\
\text { exporters }\end{array}$ & $\begin{array}{l}\text { Average exports } \\
\text { by firm (in mil.) }\end{array}$ & $\begin{array}{c}\text { Number of } \\
\text { markets }\end{array}$ & $\begin{array}{c}\text { Number of } \\
\text { exporters }\end{array}$ \\
\hline 45 & 0.08 & 6 & 27 & 0.04 & 7 & 18 \\
\hline 46 & 0.01 & 6 & 15 & 0.02 & 6 & 24 \\
\hline 47 & 0.26 & 8 & 37 & 0.18 & 9 & 28 \\
\hline 48 & 0.36 & 15 & 875 & 0.39 & 15 & 890 \\
\hline 49 & 0.21 & 15 & 1103 & 0.18 & 15 & 1020 \\
\hline 50 & 0.15 & 12 & 81 & 0.16 & 13 & 61 \\
\hline 51 & 0.39 & 15 & 148 & 0.14 & 15 & 95 \\
\hline 52 & 0.29 & 15 & 531 & 0.26 & 15 & 462 \\
\hline 53 & 0.13 & 12 & 67 & 0.45 & 14 & 94 \\
\hline 54 & 0.17 & 15 & 402 & 0.14 & 15 & 374 \\
\hline 55 & 0.18 & 15 & 488 & 0.18 & 15 & 372 \\
\hline 56 & 0.18 & 15 & 103 & 0.30 & 15 & 126 \\
\hline 57 & 0.18 & 14 & 75 & 0.15 & 15 & 66 \\
\hline 58 & 0.16 & 15 & 379 & 0.24 & 15 & 333 \\
\hline 59 & 0.26 & 15 & 190 & 0.22 & 15 & 166 \\
\hline 60 & 0.15 & 13 & 247 & 0.32 & 14 & 247 \\
\hline 61 & 0.18 & 15 & 780 & 0.22 & 15 & 750 \\
\hline 62 & 0.30 & 15 & 1446 & 0.37 & 15 & 1272 \\
\hline 63 & 0.06 & 15 & 367 & 0.13 & 15 & 382 \\
\hline 64 & 0.41 & 14 & 285 & 0.65 & 15 & 243 \\
\hline 65 & 0.04 & 14 & 78 & 0.07 & 15 & 73 \\
\hline 66 & 0.02 & 11 & 34 & 0.04 & 12 & 36 \\
\hline 67 & 0.03 & 13 & 28 & 0.03 & 13 & 25 \\
\hline 68 & 0.21 & 15 & 385 & 0.21 & 15 & 381 \\
\hline 69 & 0.24 & 15 & 487 & 0.21 & 15 & 451 \\
\hline 70 & 0.64 & 15 & 509 & 0.74 & 15 & 453 \\
\hline 71 & 0.61 & 15 & 289 & 1.35 & 15 & 309 \\
\hline 72 & 2.77 & 15 & 167 & 3.40 & 15 & 167 \\
\hline 73 & 0.24 & 15 & 1331 & 0.42 & 15 & 1342 \\
\hline 74 & 0.49 & 14 & 191 & 0.79 & 15 & 195 \\
\hline 75 & 0.90 & 12 & 38 & 2.05 & 14 & 31 \\
\hline 76 & 0.64 & 15 & 383 & 0.61 & 15 & 398 \\
\hline 78 & 0.25 & 11 & 12 & 0.11 & 8 & 12 \\
\hline 79 & 0.28 & 10 & 9 & 1.34 & 14 & 15 \\
\hline 80 & 0.06 & 11 & 25 & 0.15 & 12 & 21 \\
\hline 81 & 0.84 & 13 & 62 & 1.42 & 13 & 49 \\
\hline 82 & 0.11 & 15 & 526 & 0.14 & 15 & 510 \\
\hline 83 & 0.18 & 15 & 422 & 0.14 & 15 & 422 \\
\hline 84 & 0.83 & 15 & 4533 & 1.13 & 15 & 4478 \\
\hline 85 & 0.95 & 15 & 2258 & 1.63 & 15 & 2344 \\
\hline 86 & 0.23 & 13 & 59 & 0.52 & 14 & 80 \\
\hline 87 & 0.68 & 15 & 1708 & 1.53 & 15 & 1884 \\
\hline 88 & 11.15 & 15 & 177 & 14.36 & 15 & 232 \\
\hline 89 & 0.33 & 14 & 49 & 1.15 & 14 & 60 \\
\hline 90 & 0.48 & 15 & 1533 & 0.87 & 15 & 1537 \\
\hline 91 & 0.70 & 15 & 225 & 0.82 & 15 & 201 \\
\hline 92 & 0.51 & 13 & 58 & 0.55 & 13 & 65 \\
\hline 93 & 0.13 & 15 & 26 & 0.97 & 13 & 23 \\
\hline 94 & 0.14 & 15 & 1532 & 0.24 & 15 & 1465 \\
\hline 95 & 0.28 & 15 & 648 & 0.28 & 15 & 648 \\
\hline 96 & 0.28 & 15 & 425 & 0.31 & 15 & 368 \\
\hline 97 & 0.27 & 13 & 407 & 0.51 & 13 & 517 \\
\hline
\end{tabular}




\section{LIST OF WORKING PAPERS RELEASED BY CEPII}

An exhaustive list is available on the website: Ilwww.cepii.fr.

No

Title

2013-05 If Foreign Investment is not Foreign: Round-Trip Versus Genuine Foreign Investment in Russia

2013-04 Preferential Trade Agreements Proliferation: Sorting out the Effects

2013-03 Trend Shocks and Economic Development

2013-02 Nonlinearity of the Inflation-output Trade-off and Time-Varying Price Rigidity

2013-01 The Solow Growth Model with Keynesian Involuntary Unemployments

2012-38 Does Migration Foster Exports? An African Perspective"

2012-37 The ECB Unconventional Monetary Policies: Have they Lowered Market Borrowing Costs for Banks and Governments?

2012-36 The Impact of Market Regulations on Intra-European Real Exchange Rages

2012-35 Exchange Rate volatility, Financial Constraints and Trade: Empirical Evidence from Chinese Firms

2012-34 Multinational Retailers and Home Country Exports

2012-33 Food Prices and Inflation Targeting in Emerging Economies
Authors

S. Ledyaeva, P. Karhunen \& J. Walley

S. Bensassi, J. de Sousa \& J. Jarreau

C. F. Naoussi \& F. Tripier

A. López-Villavicencio \& V. Mignon

R. Magnani

H. Ehrhart, M. Le Goff, E. Rocher \& R. J. Singh

U. Szczerbowicz

A. Bénassy-Quéré \& D. Coulibaly

J. Héricourt \& S. Poncet

A. Cheptea, C. Emlinger \& K. Latouche

M. Pourroy, B. Carton \& D. Coulibaly 
2012-32 Fiscal Consolidations and Banking Stability

2012-31 The Contribution of the Yen Appreciation since 2007 to the Japanese Economic Debacle

2012-30 Are the Benefits of Exports Support Durable?

2012-29 Les dessous de la dette publique japonaise

2012-28 Invoicing Currency, Firm Size, and Hedging

2012-27 Product Relatedness and Firm Exports in China

2012-26 Export Upgrading and Growth: the Prerequisite of Domestic Embeddedness

2012-25 Time to Ship During Financial Crises

2012-24 Foreign Ownership Wage Premium: Does financial Health Matter?

2012-23 Tax Reform and Coordination in a Currency Union

2012-22 The Unequal Effects of Financial Development on Firms' Growth in India

2012-21 Pegging Emerging Currencies in the Face of Dollar Swings

2012-20 On the Links between Stock and Comodity Markets' Volatility

2012-19 European Export Performance, Angela Cheptea
J. Cimadomo,

S. Hauptmeier

\& T. Zimmermann

W. Thorbecke

O. Cadot, A. M. Fernandes, J. Gourdon \& A. Mattoo

E. Dourille-Feer J. Martin \& I. Méjean

S. Poncet \& F. Starosta de Waldemar

S. Poncet \& F. Starosta de Waldemar

N. Berman, J. de Sousa P. Martin \& T. Mayer

M. Bas

B. Carton

M. Bas \& A. Berthou

V. Coudert, C. Couharde \& V. Mignon

A. Creti, M. Joëts \& V. Mignon

A. Cheptea, L. Fontagné \& S. Zignago 
2012-18 The Few Leading the Many: Foreign Affiliates and Business Cycle Comovement

J. Kleinert, J. Martin \& F. Toubal

2012-17 Native Language, Spoken Language, Translation and Trade

2012-16 Assessing the Price-Raising Effect of Non-Tariff Measures in Africa

2012-15 International Migration and Trade Agreements: the New Role of PTAs

2012-14 Scanning the Ups and Downs of China's Trade Imbalances

2012-13 Revisiting the Theory of Optimum Currency Areas: Is the CFA Franc Zone Sustainable?

C. Couharde, I. Coulibaly, D. Guerreiro \& V. Mignon

2012-12 Macroeconomic Transmission of Eurozone Shocks to Emerging Economies

B. Erten

2012-11 The fiscal Impact of Immigration in France: a

X. Chojnicki Generational Accounting Approach

2012-10 MAcMap-HS6 2007, an Exhaustive and Consistent Measure of Applied Protection in 2007

H. Guimbard, S. Jean, M. Mimouni \& X. Pichot

2012-09 Regional Integration and Natural Resources: Who Benefits? Evidence from MENA

C. Carrère, J. Gourdon \& M. Olarreaga

2012-08 A Foreign Direct Investment Database for Global CGE Models

C. Gouël, H. Guimbard \& D. Laborde

2012-07 On Currency Misalignments within the Euro Area

V. Coudert, C. Couharde \& V. Mignon

2012-06 How Frequently Firms Export? Evidence from France

G. Békés, L. Fontagné, B. Muraközy \& V. Vicard 
No

Title

Authors

2012-05 Fiscal Sustainability in the Presence of Systemic Banks: the Case of EU Countries

A. Bénassy-Quéré \& G. Roussellet

2012-04 Low-Wage Countries' Competition, Reallocation across Firms and the Quality Content of Exports

J. Martin \& I. Méjean

2012-03 The Great Shift: Macroeconomic Projections for the World Economy at the 2050 Horizon

J. Fouré, A. Bénassy-Quéré \& L. Fontagné

2012-02 The Discriminatory Effect of Domestic Regulations on International Services Trade: Evidence from FirmLevel Data

M. Crozet, E. Milet \& D. Mirza

2012-01 Optimal food price stabilization in a small open developing country

C. Gouël \& S. Jean 
Organisme public d'étude et de recherche en économie internationale, le CEPII est placé auprès du Centre d'Analyse Stratégique. Son programme de travail est fixé par un conseil composé de responsables de l'administration et de personnalités issues des entreprises, des organisations syndicales et de l’Université.

Les documents de travail du CEPII mettent à disposition du public professionnel des travaux effectués au CEPII, dans leur phase d'élaboration et de discussion avant publication définitive. Les documents de travail sont publiés sous la responsabilité de la direction du CEPII et n'engagent ni le conseil du Centre, ni le Centre d'Analyse Stratégique. Les opinions qui y sont exprimées sont celles des auteurs.

Les documents de travail du CEPII sont disponibles sur le site : http//www.cepii.fr. 